\title{
REVIEW
}

Open Access

\section{Contributions of flexible power generation from biomass to a secure and cost-effective electricity supply-a review of potentials, incentives and obstacles in Germany}

Alexandra Purkus ${ }^{1 *}$ D, Erik Gawel ${ }^{1,4}$, Nora Szarka², Markus Lauer², Volker Lenz², Andreas Ortwein 2,5, Philip Tafarte ${ }^{3,4}$, Marcus Eichhorn ${ }^{3}$ and Daniela Thrän $2,3,4$

\begin{abstract}
Background: With wind power and photovoltaics, volatile renewables have emerged as central pillars of the energy transition. This increases the demand for flexibility options to compensate fluctuations in power generation. Focussing on the role of bioenergy as a renewable flexibility option, this article seeks to address two questions. The first is whether there is an option value of bioenergy as a provider of low-carbon flexibility in a future power system, which might justify continued technology-specific deployment support. The second question is whether existing market and policy incentives are effective in activating flexibility potentials, and what perspectives exist for increasing flexibility incentives.

Methods: The article follows an interdisciplinary approach. First, technical potentials for flexible bioenergy plants and potential systemic contributions are examined. This is followed by an economic assessment of what flexibility incentives are provided by relevant market and policy framework conditions.

Findings: Power from biomass can be well suited to provide flexible generation for grid stabilisation and residual load balancing. Biogas plants require an increase of nominal power over rated power, whereas the technical flexibilisation potential of solid biomass plants depends on specific technologies. Particularly, small-scale combined heat and power systems can deliver fast responses. For existing biogas plants, the Renewable Energy Sources Act's (EEG) flexibility premium and balancing market revenues have incentivised some changes in the production behaviour and investments in plant flexibilisation. However, decreasing spot market price levels and decreasing price variance reduce incentive strength. This also limits flexibilisation incentives for solid biomass plants. For new biogas plants, the EEG's remuneration rules set effective flexibility incentives, but 2014 reductions in remuneration rates have significantly slowed down the expansion.

Conclusions: Given high technical potentials for flexibility provision, there is an option value of keeping bioelectricity in the technology mix until more is known about its future competitiveness with other low-carbon flexibility options. To maintain this option value, there is a case for setting policy incentives in a way that continued technological development remains possible. A stringent climate policy could accelerate structural change in the electricity sector, to allow for market price signals which incentivise low-carbon flexibility provision.
\end{abstract}

Keywords: Bioenergy, Flexible power generation, Energy transition, Flexibility incentives, Renewable energy policy, Germany

\footnotetext{
* Correspondence: alexandra.purkus@ufz.de

'Department of Economics, Helmholtz Centre for Environmental Research -

UFZ, Permoserstr. 15, 04318 Leipzig, Germany

Full list of author information is available at the end of the article
} 


\section{Background}

The key role of flexibility in transitioning to a renewablesbased electricity system

Wind turbines and photovoltaic modules have emerged as central renewable energy technologies for decarbonising the German electricity sector and achieving the long-term policy objective of reaching an $80 \%$ share of renewable energy sources (RES) in gross electricity consumption by 2050 [1]. According to long-term RES expansion scenarios, they may provide about $80 \%$ of the installed renewable power generation capacity in 2050 [2]. However, wind power and photovoltaics (PV) are weather and season dependent and therefore of a volatile nature. In this situation, an increase in power system flexibility is required to ensure a secure electricity supply. In a conventional power system with low shares of volatile RES (vRES), flexibility is mainly needed to respond to fluctuations in demand; but with high shares of vRES, it becomes necessary to manage large-and at times rapid-fluctuations in supply as well [3]. In an electricity system based predominantly on vRES, reliable, fast and cost-effective responses are required when electricity generation from wind and PV plants drops rapidly (be it due to predicted or unforeseen weather changes), but also when there is a surplus of supply that needs to be absorbed into the system [3].

Meanwhile, flexibility is not limited to the technical ability to respond to fluctuations, but also encompasses the willingness of different power system components to adjust demand and supply [4]. Five major kinds of actions can be identified to increase the flexibility of the power system [3-5]: (a) increase in flexible power generation by dispatchable RES (primarily bioenergy) and conventional energy sources (primarily natural gas power plants, but the flexibility of coal power plants and combined heat and power (CHP) plants can also be enhanced); (b) use of power storage systems and increased sector coupling (through power-to-gas, power-to-heat and power-to-mobility concepts); (c) demand side management; (d) grid extension for interregional transport and balancing; and (e) an improved integration of European electricity grids and markets (transnational transport and balancing).

Under climate policy aspects, low-carbon flexibility options are of particular interest. However, there are still large uncertainties about which technologies will provide cost-effective and climate-friendly options for offering flexibility in the long term. This holds particularly true for advanced power storage technologies since technological development and market implementation are still at an early stage $[6,7]$. Also, the technical and economic potential of demand side management is not clear. Theoretically, significant potentials could be tapped in residential, commercial and industry sectors, but to what share they will be realised depends on the future development of diverse technical, economic, legal and societal framework conditions [8, 9]. Among renewable power generation technologies, bioenergy currently constitutes the most mature dispatchable RES (dRES) option to serve flexibility demands $[10,11] .^{1}$ As a solid, liquid or gaseous energy carrier, biomass can be easily stored, so that bioelectricity plants can produce demand-oriented; moreover, they can easily provide balancing power because of short ramp down and ramp up times at least within certain operation conditions (<15 min) [11]. However, bioelectricity generation remains more expensive than electricity generation from wind or solar power; compared to these, learning curve effects have led to less pronounced cost reductions, due to the importance of feedstock costs for generation costs and far lower unit production numbers $[12,13]$.

\section{Approach and structure of the article}

Focussing on bioenergy as a renewable flexibility option in the electricity sector, this article follows an interdisciplinary approach to address two questions. The first is whether there is an option value of bioenergy as a provider of low-carbon flexibility in a future power system with large shares of vRES, which might justify continued financial support for further bioenergy installations. In this context, we understand "option value" [14] as the value of continuing technology development and maintaining a share of bioenergy provision in the renewable energy mix, based on the rationale that it may prove to be a cost-competitive flexibility option in the future. Answering this first question requires an examination of technical potentials and systemic contributions of bioelectricity production with regard to flexibility provision. The second question is whether existing market and regulatory incentives provide adequate remuneration for the current and future value of bioenergy as a flexibility option and whether they are effective in activating flexibility potentials. Based on this economic assessment, we discuss perspectives for increasing flexibility incentives and removing potential obstacles to adjustments in plant design and production behaviour. To answer these questions, the article synergises results from various research activities undertaken by the authors, complemented by a review of insights from the academic literature.

As to whether existing market and political framework conditions set adequate incentives for flexibility provision, there are still many open questions $[4,15,16]$. Here, we focus on bioenergy as a flexibility option, where the design of RES deployment support policy still has an important impact on the overall incentive structure. Meanwhile, we do not conduct a comparison between different technological alternatives for flexibility provision (see, e.g. $[15,17-20]$ for reviews of alternative 
flexibility options). Also, we do not assess overall flexibility needs of the current and future electricity system (see, e.g. [21-23]). Germany is used as a case study because of the high relevance of vRES for the achievement of RES targets (in 2016, RES power production covered $31.7 \%$ of gross electricity consumption, and $61.4 \%$ of this was generated from wind (on- and offshore) and PV [24]), and the dynamic development of political support for bioenergy as a potential flexibility option. The following "background" sections briefly present relevant political framework conditions and the status quo of bioelectricity production in Germany, followed by an introduction of central concepts used in the article.

\section{Political framework conditions for biomass use in the German electricity sector}

As an innovative RES technology which would not be able to compete with conventional energy technologies under market conditions, bioelectricity has been supported by the Renewable Energy Sources Act (Erneuerbare-EnergienGesetz, EEG) since 2000. By offering technology- and, at times, substrate-specific remuneration for renewable electricity feed-in, the EEG has had a significant impact on bioenergy technology development and production behaviour ([25, 26] p. 320ff.). Up to 2012, the EEG has primarily promoted base load-oriented plant concepts and production behaviour, because fixed feed-in tariffs (FIT) per kilowatt-hour incentivise a maximisation of full-load hours independent of demand and electricity prices. With a shift to direct marketing and a sliding feed-in premium (FIP) from 2012, policymakers have strived to incentivise flexible production behaviour (e.g. voluntary curtailment in times of low or negative electricity prices, participation in balancing markets, aligning maintenance with hours of low electricity prices), a flexibility-oriented design of new plants (e. g. with a higher nominal capacity than rated capacity) and technical adjustments of existing plants (e.g. enlargements of gas storage tanks) [10, 27, 28]. However, the 2014 reform of the EEG has also seen a critical debate about RES support costs in general and bioelectricity generation costs in particular [29]. As a result, the 2014 amendment of the EEG significantly reduced incentives for the further development of bioelectricity [30], by reducing remuneration rates and introducing a $100 \mathrm{MW}_{\mathrm{el}}$ cap on the gross annual expansion of biomass capacities. In order to improve costeffectiveness and quantitative control over RES expansion, the EEG 2017 reform adopted a tendering scheme for wind, PV and biomass, introducing a competitive element to RES support [31]. As long as certain flexibility requirements are met, bioenergy tenders are open for participation of existing plants-this is because after the end of their 20-year period of guaranteed EEG remuneration, a continued operation would in many cases not be profitable given market incentives alone ([32] p. 3). Bids will be invited for an annual
$150 \mathrm{MW}_{\mathrm{el}}$ in bioelectricity capacity from 2017 to 2019, increasing to $200 \mathrm{MW}_{\mathrm{el}}$ from 2020 to 2022 [33] (see Table 1 for more details). The first bioenergy tender was held in September 2017 [34].

\section{Status quo of bioelectricity production in Germany}

Electricity production based on biomass was about 43.8 TWh in Germany in 2016 (excluding the biogenic share of waste), contributing $23 \%$ to gross electricity production from renewable energies [35]. Plants based on solid biomass accounted for $25.1 \%$ of bioelectricity production, biogas and biomethane plants for $73.9 \%$ and liquid biomass-based plants for $1 \%$ [35]. Overall, biogas plants play the most important role for bioelectricity generationin 2016, 8400 agricultural biogas plants with a rated capacity of $4.1 \mathrm{GW}_{\mathrm{el}}$ and ca. $0.55 \mathrm{GW}$ flexibly available capacity were in operation, as well as ca. 115 organic waste digestion plants with an installed capacity of $115 \mathrm{MW}_{\mathrm{el}}$ [36] (for the distinction between rated and installed capacity, see the "Technical potentials for flexible bioelectricity supply" section below). Solid biomass plants accounted for an installed capacity of ca. $1.6 \mathrm{GW}_{\mathrm{e}}$, with about 700 EEG-remunerated plants in operation (including wood gasification plants, but not counting plants $\left.\leq 250 \mathrm{~kW}_{\mathrm{el}}\right)$. Seven hundred twenty plants were based on bioliquids with an installed capacity of $90 \mathrm{MW}_{\mathrm{el}}$ [36]. Moreover, 196 plants processed biogas to biomethane in 2016 with a gas feed-in capacity of 31 PJ [36]. Biomethane is mostly (ca. 70\% in 2015) utilised in biomethane block heat and power plants which numbered ca. 1400 with an installed capacity of $330 \mathrm{MW}_{\mathrm{el}}$ in 2015, while the remainder is traded or used in heat and transport sectors [37].

The development of total bioelectricity production over time is illustrated in Fig. 1. Between the implementation of the EEG 2014 in August 2014 and April 2017, the gross expansion of installed capacity was only $119.75 \mathrm{MW}_{\mathrm{el}}$ for newly registered bioelectricity plants [38]. Over the same period, there was a $342.95 \mathrm{MW}_{\mathrm{el}}$ increase in the installed capacity of plants which had been operational since before the EEG 2014 and added additional capacity to receive the flexibility premium (see below the "Policy incentives for flexible power generation from biomass" section) [38]. The response to the first tender round was reserved-only 33 bids with a total capacity of $41 \mathrm{MW}$ competed for a tendered quantity of $120 \mathrm{MW}$ [34]. Of these, 9 were excluded for formal reasons, leaving 24 successful bids with a total capacity of $27.5 \mathrm{MW}$ (20 existing plants, 4 new plants). The average reference price resulting from the bids was $14.81 \mathrm{ct} / \mathrm{kWh}$ for new plants and $14.16 \mathrm{ct} / \mathrm{kWh}$ for existing plants, and therefore,--especially for new plants-close to the price cap [34].

\section{Relevant concepts: flexibility, incentives and potentials}

As key concepts used in the paper, flexibility, incentives and potentials shall be briefly defined in the following. 
Table 1 Development of bioelectricity deployment support design (based on subsequent versions of the Renewable Energy Sources Act (EEG))

\begin{tabular}{ll}
\hline EEG version & Major instrument characteristics \\
\hline EEG 2000-EEG 2009 & $\begin{array}{l}\text { Fixed feed-in tariffs (FIT) per kilowatt-hour; } \\
\text { electricity marketed centrally by transmission } \\
\text { system operators }\end{array}$
\end{tabular}

EEG 2012

Introduction of sliding feed-in premium (FIP) in combination with direct marketing and flexibility premium for biogas plants on an optional basis

EEG 2014

- Direct marketing obligatory for new plants, in combination with administered FIP (from 2016, FIT only remains available for new plants $\leq 100 \mathrm{~kW}$ )

- Reduction of bioelectricity remuneration rates and introduction of $100 \mathrm{MW}_{\mathrm{el}}$ cap on the gross annual expansion of biomass capacities (if exceeded, remuneration rates undergo an accelerated decrease)

- Flexibility premium for biogas plants is continued

EEG 2017 - Introduction of tenders for wind, PV and biomass

- Bioenergy tenders: for all new plants $>150 \mathrm{~kW}_{\mathrm{el}}$ (plants $\leq 150 \mathrm{~kW}_{\mathrm{el}}$ receive the administered FIP; plants $\leq 100 \mathrm{~kW}_{\mathrm{el}}$ the fixed FIT)

- Bids relate to the reference price for the sliding FIP

- Remuneration is awarded "pay as bid" (except for existing plants $\leq 150 \mathrm{~kW}_{\mathrm{el}}$ which can opt for participation and receive remuneration according to the highest successful bid)

- Bids are limited by a price cap (subject to annual degression): $14.88 \mathrm{ct} / \mathrm{kWh}$ for new plants and $16.9 \mathrm{ct} / \mathrm{kWh}$ for existing plants in 2017 (to compare_-administered reference prices under the EEG 2014 were $13.66 \mathrm{ct} / \mathrm{kWh}$ for plants $\leq 150 \mathrm{~kW}$ el, less for larger plants, see $\S 44$ EEG 2014) ${ }^{2}$

- Successful new plants receive the FIP for 20 years, existing plants (which can participate if 8 years or less of their EEG remuneration period remain) for 10 years

- Flexibility premium for biogas plants is continued

Flexibility can be understood as the ability of a power system to "respond rapidly to large fluctuations in demand and supply, both scheduled and unforeseen variations and events" ([3] p. 13). Specifically, large shares of vRES in the electricity mix need to be accompanied by an increase in flexibility in the following fields:

1) Grid stabilisation: short term reaction to unpredictable fluctuations, $<15$ min reaction time.

2) Balancing of residual load (calculated as the difference between supply from vRES and power consumption): midterm reaction to more or less predictable fluctuations, $>15$-min reaction time.
Moreover, low carbon options for providing ancillary services (e.g. frequency and voltage stability, support of the grid restoration process, congestion management) are required in order to reduce must-run capacities of fossil fuel-based power plants [39]. Additionally, there is a need to balance seasonal fluctuations in wind and PV energy provision (long term-up to half a year). However, since no rapid response of electricity generation or load capacities is necessary here, the problem may be framed as one of adequacy of energy supply rather than flexibility, and is not in the focus of this paper. Furthermore, the optimal combination of wind and PV reduces seasonal fluctuations in the energy system $[40,41]$.

To implement an increase in flexibility, the question of whether there are incentives to adjust production behaviour according to demand on electricity markets or invest in flexible plant designs is crucial. On a general level, incentives result from changes in the costs and benefits associated with certain behaviours; they can be monetary or non-monetary. The main focus of this paper lies on monetary incentives, which are determined by the costs of investing in flexibility or changing production behaviour on the one side, and the benefits which accrue from the remuneration of flexibility on the other side. This remuneration may be offered by markets (such as balancing markets, intraday and day-ahead markets) or policy instruments, and it may be tied to the fulfilment of predefined criteria (e.g. prequalification requirements in balancing markets, technical requirements in the EEG).

When speaking of potentials, it seems useful to distinguish theoretical, technical, economic and market potentials (based on [42] p. 963f., [23]). In the context of energy potentials, the theoretical potential describes a resource's (e.g. biomass) physical or chemical energy content, whereas the technical potential refers to the energy content that can be made accessible given technological, engineering and topographical constraints. The economic potential takes all social costs of fuels and technologies into account, as well as the competitiveness of a technology's contribution compared to relevant alternatives. The market potential is the part of the economic potential that is profitable to develop from a business perspective, taking market and policy incentives into account. In our technical analysis, we focus on the technical potentials for flexible bioelectricity provision; we discuss the extent to which existing or new plants can be flexibilised and existing technical options for doing so. In combination with the assessment of systemic contributions, this helps to better understand the option value of flexible bioelectricity production. The economic potential, however, is associated with high uncertainties; estimates depend on, inter alia, assumptions about future biomass price developments, learning curve effects for bioelectricity plants as well as future cost 


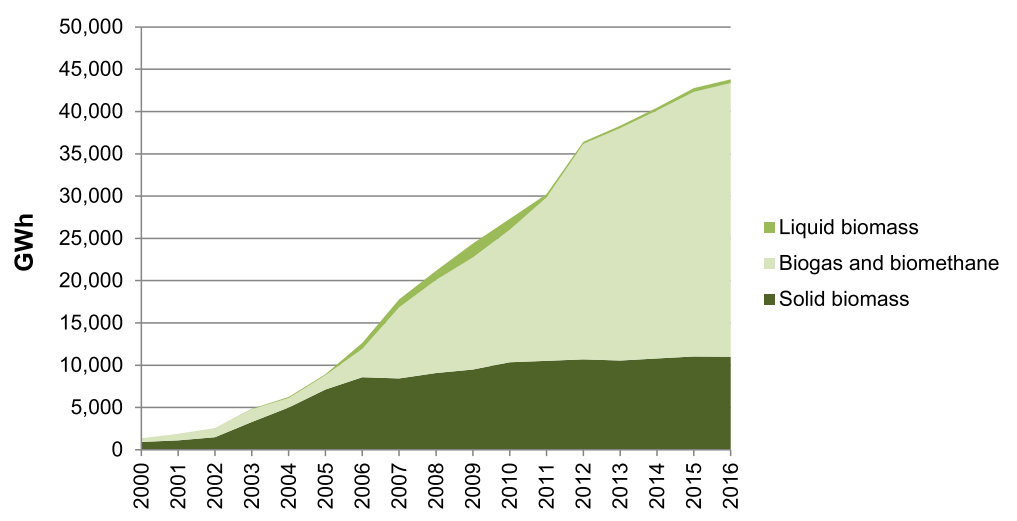

Fig. 1 Development of bioelectricity production in Germany 2000-2016 (source: own representation based on [35]). Note: the biogenic share of waste in waste incineration plants is not included. Data for solid biomass encompass sewage sludge from 2010

developments of low-carbon flexibility alternatives. Further assumptions would need to be made regarding the external costs and benefits associated with different technologies. Meanwhile, estimates of future market potentials for flexible bioelectricity production would be highly speculative, because they depend on the future development of remuneration perspectives which are influenced by future energy and climate policy design as well as electricity and balancing market design. For example, estimates of longer-term spot market price developments differ considerably between studies and scenarios, as they depend on, e.g. assumptions about $\mathrm{CO}_{2}$ certificate prices in the European Emissions Trading System (EU ETS), fuel prices and the composition of the electricity mix [43]. Also, while an increasing market share of vRES tends to increase electricity price volatility [44], this development is influenced by the future design of remuneration rules (e.g. concerning FIP payments in hours with negative electricity prices) and the diffusion of new flexible technologies [45].

Finally, when discussing expansion potentials for bioenergy, ecologically sustainable biomass potentials available for energetic uses are relevant [46, 47]. However, given the current political debate, we do not analyse what level of expansion would be feasible and sustainable given biomass potentials but focus on the question whether the role of bioenergy as a flexibility option justifies continued political support for installations and technology development.

\section{Findings}

\section{Technical potentials for flexible bioelectricity supply}

In this section, we discuss bioenergy plants' technical potentials for flexible electricity supply. In principle, flexible plant design and operation is possible for biogas, solid biomass and bioliquid-based plants. However, vegetable price developments and competition for bioliquids with the transport sector limit the economic relevance of the latter option [11] (see also Fig. 1), so that the following discussion will focus on biogas plants and solid biomass plants. For a more in-depth discussion of different bioenergy technologies' flexibility characteristics, see [11, 48].

Biogas plants are the most important controllable renewable energy in the German electricity system [37]. The technical potential of biogas in Germany is estimated at about 357 PJ [30]. With consideration of an electrical efficiency of $40 \%$, the technical potential for the electricity generation from biogas plants is $40 \mathrm{TWh}_{\mathrm{el}}$. This would be an increase of over $40 \%$ compared to the current electricity generation from biogas plants in Germany [37]. The technical potential of flexible biogas plants depends on the quotient of rated and installed, nominal capacity of biogas plants (power quotient $\mathrm{PQ}=P_{\text {nom }} / P_{\text {rated }}$ ) (see [48]). Rated capacity is defined as the quotient of annual electricity generation and the hours within one calendar year. An annual electricity generation of $40 \mathrm{TWh}_{\mathrm{el}}$ corresponds to a rated capacity of $4.6 \mathrm{GW}_{\mathrm{el}}$. If biogas plants are to generate power in a flexible way, rated capacity (i.e. the power generated over a certain period of time) needs to be smaller than nominal capacity (i.e. the potential power generation over the same time period)-the higher the $\mathrm{PQ}$, the greater the degree of flexibilisation. In the given example, a PQ of 2 or 4 leads to maximum peak load generation of 9.2 or $18.4 \mathrm{GW}_{\mathrm{el}}$, respectively. However, the flexibilisation of biogas plants and the increase of the PQ ask for investments in additional CHP and gas storage capacities. Simultaneously, an increasing peak load generation reduces daily operating times of biogas plants, which influences the benefit from flexible power generation. Due to increasing additional investments in components for flexible power generation, the market potential of flexible biogas plants has to take into account the marginal utility of demand-driven generation. Moreover, the grid 
connection capacity can be a bottleneck for the decentralised power generation from biogas plants. Depending on this capacity the maximum power generation and $\mathrm{PQ}$, respectively, can be restricted by the grid operator.

As for solid biomass CHP plants, the technical potential for flexible bioelectricity supply is strongly dependent on the actual technology used. The main technologies for power production from solid biomass include steam cycles, Organic Rankine Cycles (ORC), and gasification systems. Specific designs (e.g. strong brick walls in the furnace to stabilise combustion of low-grade fuels) might decrease the flexibilisation potential. Technologies with storable intermediate energy carriers (like synthesis gas or synthetic fuels) on the other hand have a high potential for flexibilisation. An overview of technical options for flexible operation of solid biomass CHP systems is given in ([49] p. 64, Table 4.5).

A high potential for further flexibilisation of bioenergy from solid biomass may be achievable by implementation of small-scale CHP systems (examples for solid biomass gasifiers with small-scale CHP technology which are already marketed today include Spanner, Entrade, SynCraft, Burkhardt and others). Due to their size and low thermal inertia, these systems are considered to be highly flexible. By implementing those systems close to the consumers of heat and power, advanced automation can provide heat and power on demand. Such systems can help stabilise local supply grids, minimise local peaks in power demand or supply and provide stable energy supply for island grids.

Consequently, for new small-scale systems, a high flexibility between zero and full load is in development. Due to economic reasons, all the produced heat has to be used, but intermediate storage in a hot water buffer is possible. The potential capacities to flexibly provide combined heat and power are quite high, as today in Germany, about one million small-scale boilers for biomass are used and almost as many could be switched to CHP Technologies until 2050 (amounting to an estimated $5 \mathrm{GW}_{\mathrm{el}}$ based on today's heat operation; together with an increased storage of heat (including biogas in natural gas distribution networks), this could be raised to $\left.10 \mathrm{GW}_{\mathrm{el}}[50]\right)$. $^{3}$ This perspective remains relevant even if a sizable decrease of heat demand could be realised by means of insulation and low-energy standards for new houses; in such a scenario, the scale of the CHP systems could be further reduced, and they could be combined with local heating grids.

Even if solid biomass plants produce intermediates, storability is not as easy as with biogas. Gasification products are typically hot, with a significant amount of their energy content contained within the temperature of the gas. For storing the gas, it has to be cooled down, preferably with additional heat recovery to reduce losses in energy efficiency. Also, separate gas storage is needed, which for small-scale utilities could be problematic from a safety point of view. The advantage of small-scale units is that it is the usual practice to operate them only for some hours of the year (e.g. a typical house heating pellet boiler may run for $1600 \mathrm{~h} /$ year). As a result, flexibilisation by shifting the running time (as long as the heat is storable for full use) will not reduce operation time, so that costs are only slightly affected by a more expensive flexible technology.

As already mentioned, one of the main restrictions for small-scale units is the demand for the heat use. It is not a big problem to store the heat for one or 2 days, but within this timeframe, the heat should be fully used. With new control systems which include weather data, there are helpful options for calculating the future heat demand available. Furthermore, small-scale CHP Technologies will probably need high-quality fuels for flexible operation, so the fuel supply and its costs could also be an obstacle (e.g. charcoal pellets or proven quality torrefied pellets).

Taking a more long-term perspective, future renewable heat supply will be based much more on heat pumps and solar thermal energy than today. Additionally, combining electrical heating elements with hot water buffers is an option for negative power regulation. Therefore, the basic heat supply will also be fluctuating, with the positive effect that almost all buildings will be equipped with hot water buffers. As a result, there would be no additional costs for biomass CHP for heat storage. Heat pumps can also provide some negative power regulation, but at very cold times, they have to run with low efficiencies whenever needed unless an alternative renewable heat source is available. Small-scale biomass CHP can have a double effect during those times by replacing power demand for heating by heat pumps and producing positive residual load at the same time.

Large existing solid biomass power plants, meanwhile, could also run more flexibly at least in a certain range of power, as soon as they are refinanced. This is because as soon as capital costs are recovered, overall costs are more or less proportional to running time. For new plants, on the other hand, a reduced running time would lead to higher average costs per megawatt-hour or longer amortisation periods.

Table 2 summarises technical flexibilisation opportunities for biogas and solid biomass CHP plants. Given short timescales for power variations, bioenergy plants can make a contribution both to grid stabilisation (with $<15$ min reaction time) and the balancing of residual load (> $15 \mathrm{~min}$ reaction time). Meanwhile, when interpreting technical potentials for flexible bioelectricity supply, not only uncertainties regarding ecologically sustainable biomass potentials need to be taken into account $[46,47]$. There are also uncertainties about the 
Table 2 Overview of technical flexibilisation opportunities for different bioelectricity technologies (based on [11, 19, 36, 37, 49])

\begin{tabular}{|c|c|c|c|c|}
\hline Bioelectricity technology & $\begin{array}{l}\text { Power variation } \\
\text { range "eOut" (\%) }\end{array}$ & $\begin{array}{l}\text { Timescale for power variation } \\
\text { "ramp up" }\end{array}$ & $\begin{array}{l}\text { Timescale for power variation "ramp } \\
\text { down" }\end{array}$ & $\begin{array}{l}\text { Technical potential for } \\
\text { flexible bioelectricity } \\
\text { supply }{ }^{1}\left(\text { TWhel }_{\text {el }}\right)\end{array}$ \\
\hline Biogas plants & $0-100$ & $\leq 5 \min (0 \%$ to nominal load $)$ & $\leq 5 \min$ (nominal load to $0 \%$ ) & 40 \\
\hline Solid biomass CHP & $0-100$ & $0.3 \%$ point per min for $30-100 \%$ & $1 \%$ point per min for $30-100 \%$ & 10 \\
\hline Solid biomass gasification plants & $0-100$ & $1 \%$ point per $\min$ for $50-100 \%$ & $10 \%$ points per $\min$ for $50-100 \%$ & 10 \\
\hline
\end{tabular}

${ }^{1}$ For estimating the technical potential for future flexibility provision from solid biomass plants, their current CHP electricity production level of $18 \mathrm{TWh}_{\mathrm{el}}$ provides an upper limit [36]; taking flexibility restrictions and a likely future reduction in production into account, the technical potential may amount to ca. $10 \mathrm{TWh}_{\mathrm{el}}$

future utilisation of biomass in sectors other than the power sector, e.g. for heat production, industrial processes, transport fuels or material uses [51, 52]. This can reduce available biomass amounts for bioelectricity production, including its flexible provision. In case of a combined utilisation of biomass, additional operational constraints can reduce the flexibility that bioenergy can provide for the power sector. However, while there are many alternative uses for available biomass potentials, flexibility provision is-according to current knowledge-an area where bioenergy can make an important contribution as the energy transition progresses towards a decarbonised energy supply with a high share of vRES $[2,53]$.

\section{Systemic contribution of bioenergy for balancing vRES}

From a systemic perspective, the structure and extent of future demand for flexible power generation from biomass will depend on the specific conditions and infrastructural framework in which bioenergy is contributing to an environmentally friendly and secure power system. Especially in power systems with high shares of vRES, limited demand-side management as well as power storage infrastructure, fluctuations in residual load (RL) are becoming a major challenge for a balanced power system $[19,54]$. The following section explores the future contribution of bioenergy plants to balancing residual load, which will become more relevant as the diffusion of vRES increases. Bioenergy's role in grid stabilisation is discussed in the "Market incentives for flexible power generation from biomass" section, as plants already offer control power in today's balancing markets.

One major mitigation strategy that focuses on the supply side of balancing RL is the optimization of vRES technologies and their integration into future power systems, in a way that the demand for additional infrastructure (power grids, storage, conventional backup power plants, but also flexible biomass) to compensate for RL fluctuations is reduced at the very beginning, when fluctuating RES are transformed into electrical power. For example, a power supply system largely dependent on solar has to deal with huge daily supply fluctuations between day and night as well as with seasonal fluctuations between summer and winter. In comparison, a mix of different vRES sources (solar, wind, hydro, tidal) with complementary temporal production patterns and optimised technical design of wind and solar PV installations [55-57] can mitigate significantly the required infrastructure for balancing future fluctuations in RL [58-60].

Furthermore, bioenergy can make a contribution to balancing vRES (e.g. [61]). This has been examined in two case studies developed for different control areas in Germany's transmission grid [41, 62], which estimated the development of RL in coming years and assessed the potential of flexible biomass to reduce RL fluctuations, largely caused by increased shares of variable renewables feed-in. RL is expected to have a wider spread between maximum and minimum RL values, with minimum turning into negative figures, equivalent to overproduction from renewables $[63,64]$.

Figure 2 shows the residual load duration curve, the descending order of all RL values of a time period, for the year 2011 and 2012 (red line) and projections (blue line for non-optimised and green for optimised systems including system friendly layouts and optimised technologies) for 2030 for the TRANSNET-BW transmission grid in Germany.

It becomes apparent from Fig. 2 that on the one hand, future RL is lowered due to renewables feed-in and therefore shifted downwards in the graph compared to the RL in 2012. On the other hand, optimised renewables reduce the required flexibility compared to nonoptimised renewables as fewer hours of negative RL and connected excess energy are produced. This indicates that there is a certain range of possible future demand for flexibility, although only the renewable mix and the technologies wind and solar PV have been modelled and many other important factors excluded (for a more detailed discussion, see $[41,62])$.

Moreover, the possibility of current flexibility concepts for bioenergy to adapt to the remaining RL fluctuations, as they have been laid out in the "Technical potentials for flexible bioelectricity supply" section, has been investigated (see also [41]). Bioenergy flexibility concepts have been tasked to offset daily fluctuation in RL for a 2030 scenario in the $50 \mathrm{~Hz}$ transmission grid. Flexible bioenergy is modelled to reduce daily variability in $\mathrm{RL}$, so that power output is increased in high RL situations and reduced when low or even negative RL occur. Here, 


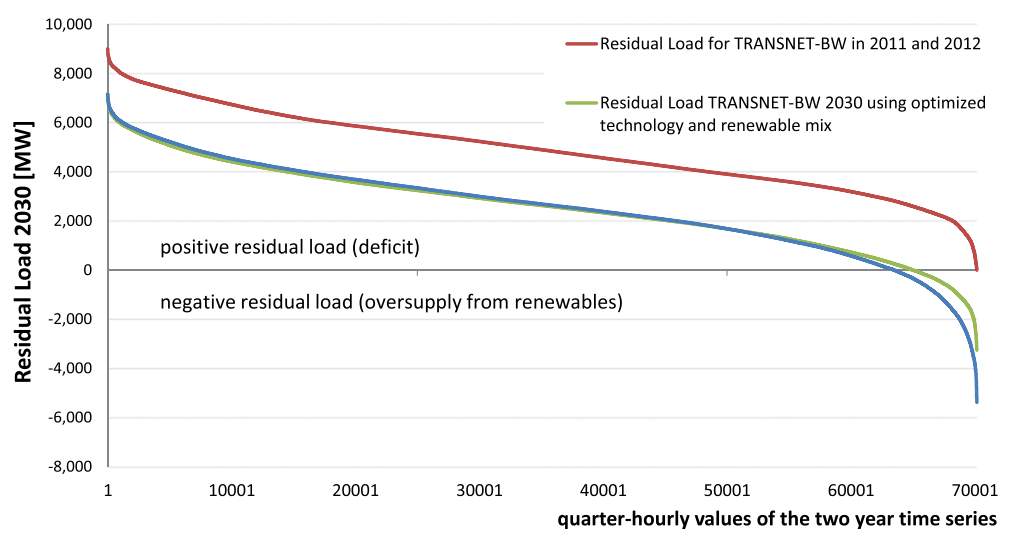

Fig. 2 Residual load duration curves (as difference of demand and renewable power generation capacity at a time) for one of Germany's four transmission control areas in 2011 and 2012 (red line) and projections for 2030, with (green line) and without (blue line) optimised technologies and renewable mix (source: own data and illustration)

flexible bioenergy has proved to be effective in reducing daily variability in residual load by over $50 \%$ on average over the course of 1 year. Especially, biogas plants with on-site gas storage are for example well suited to offset the daily feed-in pattern from solar PV systems (see the following Fig. 3).

In contrast, extended periods of high feed-in from wind, which is typical for autumn and winter time in Europe, are challenging the existing flexibility concepts for biogas plants without methanation, as these are not able to avoid power production over longer periods with negative RL (excess power with power production from renewables greater than demand) and wind power already serving power demand.

Future flexibility concepts could therefore include additional technical solutions like feed-in management of the biogas process, which enables to adapt in advance to prevailing low RL periods. Options like biogas upgrading and injection into the natural gas grid would allow making use of existing infrastructure that can serve as a storage system for biogas, comparable to the concepts for power to gas (P2G) [65]. Natural gas can afterwards be used whenever and wherever high demand for power is required.

At the same time, linking biogas plants with the natural gas grid would allow to unlock the increased power installations of flexible biogas plants for the purpose of supplying secured power, for example for the rare instances of extended periods of non-availability of other renewable power generation. This way, the increased capacities of flexible power plants are enabled to provide power unrestricted to the biological processes of the biogas plant on site and would increase their value.

For future power supply systems with high shares of vRES and limited system flexibility (power storage, power grid, demand-side management), flexible bioenergy is capable of contributing to the maintenance of balanced power systems while at the same time providing clean and demand-driven power to achieve renewables goals.

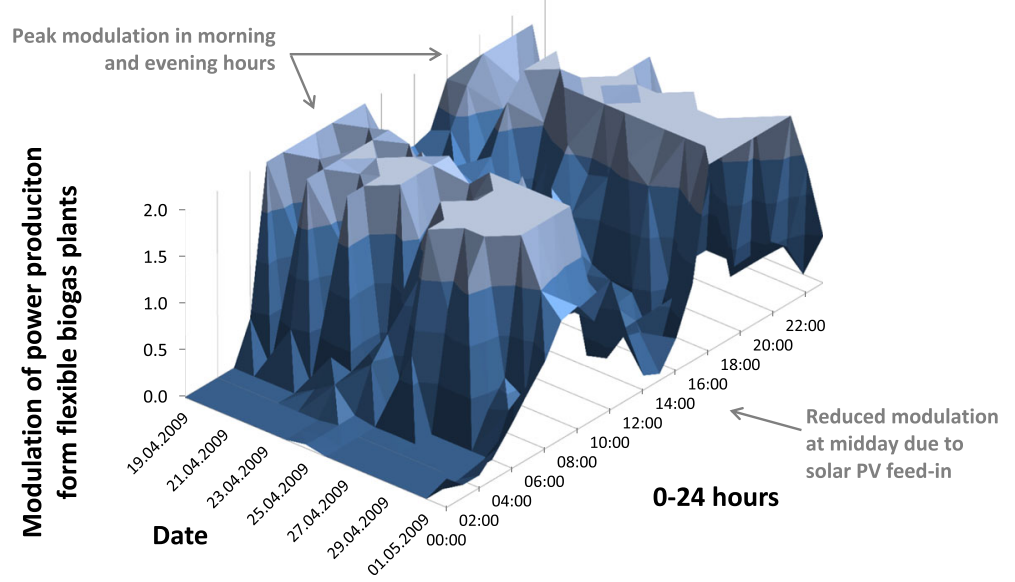

Fig. 3 Flexible power production from biogas plants over the course of 12 days with high feed-in from solar PV. Power output is reduced at midday to compensate for high feed-in from solar PV (source: own data and illustration, reproduced from ([41], p. 154) 
For the current state of transition towards a renewable power system in Germany with a RES share in gross electricity consumption of $31.7 \%$ in 2016 [24], the requirement for flexible power provision from bioenergy is still limited on a national scale. However, with individual regions well ahead of the national average RES share, flexible bioenergy can be an asset to maintain system stability from a regional perspective, especially in regions with weak grid infrastructure. As a consequence, flexible power generation from biogas plants can reduce investments in grid extensions [66]. In coming years and on road to the German electricity sector RES share goals of $55-60 \%$ by 2035 and $80 \%$ by 2050 ( $\$ 1$ (2) EEG 2017), flexibility options such as dispatchable bioenergy can be expected to become even more important [67].

\section{Assessment of current production behaviour and flexibility incentives}

Incentives for flexible plant design and production behaviour can arise from electricity and balancing markets and from policy instruments. In the following, existing flexibility incentives are discussed for the case of Germany; then, their effectiveness in affecting the current production behaviour of biogas and solid biomass plants is assessed.

\section{Policy incentives for flexible power generation from biomass}

Bioelectricity plants in Germany traditionally operate with continuous electricity production, due to the incentives provided by a fixed FIT paid per kilowatt-hour (see introduction). From 2012 on, policymakers introduced several measures to incentivise more demand-oriented production:

- Shift from fixed FIT to a sliding FIP (market premium), which makes total remuneration partly dependant on market prices (\$ 33g EEG 2012; $\$ 34$ EEG 2014).

- Flexibility premium for biogas plants and biomethane combined heat and power units (CHPU) (\$ 33i EEG 2012; \$\$ 52-54 EEG 2014).

- Enabling participation in balancing markets only for plants in direct marketing (see $\mathbb{\$} 16$ (3) EEG 2012; $\mathbb{S}$ 39 (2) EEG 2014).

- Funding for new biogas plants above $100 \mathrm{~kW}$ is limited to the part of annual electricity production that corresponds to a power rating of $50 \%$ of the installed electric capacity ( $\$ 47$ (1) EEG 2014), to set incentives only for flexible biogas plants which focus electricity production on hours of high demand. This rule applies also to biogas plants under the EEG 2017 (\$ 39h (2) No. 1 EEG 2017). For solid biomass-based plants, funding can only be claimed for annual electricity production that corresponds to a power rating of $80 \%$ of the capacity approved in the bid (\$ 39h (2) No. 2 EEG 2017).

The market premium was introduced under the EEG 2012 on an optional basis, allowing plant operators a monthly choice between receiving the FIT and leaving the marketing of electricity to transmission system operators (TSOs), or receiving the sliding FIP and marketing electricity directly. An exception was large biogas plants $>750 \mathrm{~kW}$ which were only eligible for the FIP from the beginning of 2014 (\$S 27 (3), 27a (2), 27c (3) EEG 2012). Under the EEG 2014, direct marketing has been made obligatory for all but small-scale plants, with the market premium as the standard mode of remuneration (from 2015, all new RES plants $>500 \mathrm{~kW}_{\text {el }}$ have to participate in direct marketing, from 2016 this is the case for all new plants $>100 \mathrm{~kW}_{\mathrm{el}}(\mathbb{S} 37$ EEG 2014)). The market premium pays for the difference between a set reference price and the average market value of the electricity generated, calculated on a monthly ex-post basis. Plant operators which sell electricity primarily when market prices are high can generate revenues above the average market values used in the premium's calculation, resulting in incentives for demand-oriented production [27, 68]. However, the strength of these incentives depends on the spread between base and peak hour prices on EPEX spot markets (i.e. dayahead and intraday markets).

As opposed to plants in the FIT scheme, plants in direct marketing can earn additional, market-based revenues by providing system services, such as offering control power in balancing markets (see [25]). Meanwhile, direct marketing also provides incentives for improving the efficiency of marketing concepts. For example, flexibility need not be provided by each plant in isolation, but it is also possible to combine several dRES and vRES plants in virtual plants with a joint dispatch strategy [69]. Figure 4 illustrates the development of direct marketing of bioelectricity production since the introduction of the optional market premium in 2012, compared to centrally marketed bioelectricity quantities handled by the TSOs. In 2015, 72.5\% of biomass-based renewable electricity production participated in the market premium scheme in combination with direct marketing.

The flexibility premium payment was introduced alongside the market premium in the EEG 2012 and continued-in slightly adjusted form-in the EEG 2014 [70]. It can be claimed for biogas plants and biomethane $\mathrm{CHP}$ units, as long as their technical ability to operate flexibly is certified ( $\$$ 33i (1) No. 4 EEG 2012; Annex 3 (I) No. 1 EEG 2014). 


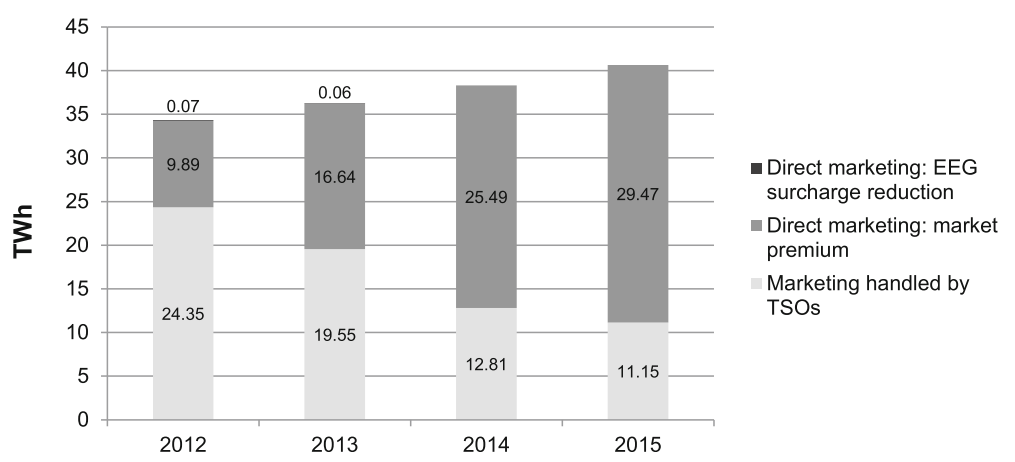

Fig. 4 Development of different marketing forms for bioelectricity production over time (in TWh, 2012-2015, source: own representation based on [123]). Note: the EEG 2014 abolished the so-called green electricity privilege, which offered electricity suppliers a reduction in the EEG surcharge if a certain percentage of their electricity supply was sourced directly from marketed RES. Other forms of direct marketing which do not receive remuneration under the EEG are not displayed, as amounts are very small

The goal of the flexibility premium is to encourage investments in components which are necessary for demandoriented electricity generation. For existing plants, these components are primarily new or additional CHP and gas storage capacities for biogas plants. The level of the premium payment for flexibility depends on the quotient of rated and installed capacity (power quotient, $\mathrm{PQ}$ ) of biogas plants and biomethane CHPU (Annex 5 EEG 2012; Annex 3 (II) EEG 2014). As a result, biogas plants and biomethane CHPU with a high PQ value, which can be achieved, e.g. by increasing the installed capacity while holding the rated capacity constant, receive higher subsidies. Given the EEG 2014's limit of funding to the annual electricity production corresponding to a power rating of $50 \%$, the PQ must have a value of at least 2 . For existing plants, the flexibility premium is paid for a period of 10 years $(\$ 33 i(4)$ EEG 2012; Annex 3 (I) No. 4 EEG 2014). The EEG 2014 introduced an alternative form of flexibility premium for new biogas plants ( $\$ 53$ EEG 2014). Here, the premiums' calculation depends on the installed capacity, and the payment can be claimed over the whole period of remuneration. The EEG 2017 retains the flexibility premium for new and existing biogas plants, both for plants participating in the tendering scheme and plants receiving administered remuneration (\$\$ 50, 50a and 50b EEG 2017).

\section{Market incentives for flexible power generation from biomass}

Additional income opportunities on electricity and balancing markets are a major influence factor for decisions about plant flexibilisation and adjustments of the production profile. This poses the question whether market prices signal flexibility demand. On the EPEX Spot SE market, the profitability of a demand-oriented production strategy depends on average price levels and price variance. In the EPEX Spot SE day-ahead market, where most RES production is marketed, both indicators have fallen in recent years (see Fig. 5). ${ }^{4}$ As a result, the scope for achieving higher than average revenues in the market premium scheme by focussing electricity production on hours with high demand and high spot market prices has decreased. Furthermore, the decreasing variance of EPEX Spot SE prices and related revenues reduces the general willingness to invest in new plant components as prerequisites of flexibilisation. An increasing price variance of EPEX Spot SE would improve the economic feasibility of flexible power generation from biogas plants and biomethane CHP, but also of other flexibility options (e.g. storage systems) [18]. However, such an increase in price variance requires a reduction of excess capacities of non-flexible conventional power plants [71].

Furthermore, bioelectricity plant operators who participate in direct marketing can generate additional revenues in balancing markets. However, additional revenues by the provision of control power are not linked to whether plants are operated in a flexible mode with regard to demand on the spot market and can also be generated in base load operation-for example, a base loadoriented plant can provide negative balancing power by temporarily reducing its output. For providing positive balancing power, greater flexibilisation would be necessary because plants have to hold capacity available for expanding electricity generation on short notice. Also, flexibilisation requirements depend on the type of control power provided. Secondary control power has to be provided within $5 \mathrm{~min}$ at full capacity, while the lead time for tertiary control is higher (down to $7.5 \mathrm{~min}$ ), and capacity is called upon for at least 15 min at a constant level [72]. This results in somewhat lower flexibility requirements. Provision of primary control power requires a response within $30 \mathrm{~s}$ [72].

Meanwhile, price signals on balancing markets do not yet express growing flexibilisation needs of the electricity system. Analysing the development of German balancing markets between 2008 and 2015, Hirth and Ziegenhagen [73] find that even though the installed capacity of vRES 


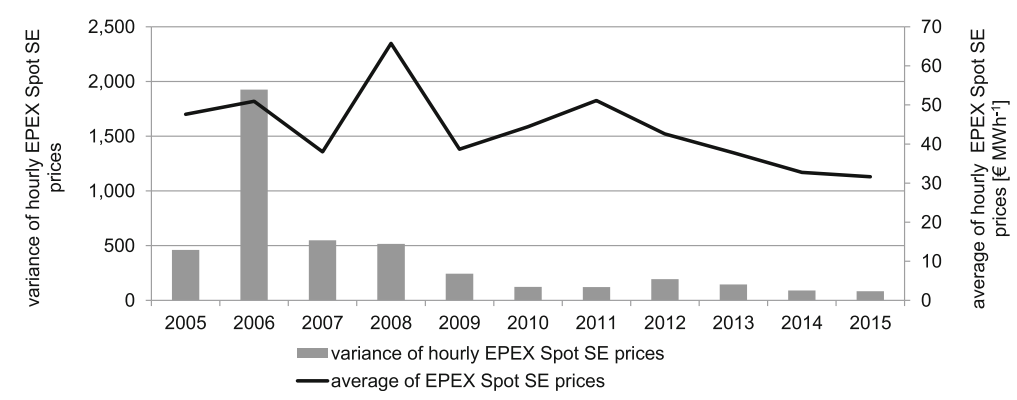

Fig. 5 Variance and average of hourly EPEX Spot SE day-ahead prices for the period 2005-2015 (source: own calculations based on [124]). Note: the variance depicts the sum of the squared deviation of hourly values of EPEX Spot SE prices in a year from the mean EPEX Spot SE price in that year

tripled, balancing reserves in Germany were reduced by $15 \%$, while the costs of balancing provision decreased by $50 \%$. In particular, the size of secondary and tertiary balancing markets has decreased, accompanied by reductions in balancing prices. Also, prices for positive balancing power were reduced more strongly than for negative balancing power [73]. High price volatility on primary, secondary and tertiary reserve markets and increasing competition due to a rising number of prequalified suppliers further limit the strength of flexibility incentives from balancing markets. While modelling studies predict that balancing reserve requirements will increase as installed vRES capacity grows, various factors are important in determining the actual development of reserve requirements (which is influenced, inter alia, by the quality of vRES and load forecasts and the degree of cooperation between TSOs) as well as price developments [73]. For example, it is to be expected that competition in reserve markets will increase further as storage technologies, vRES and controllable loads enter as additional players, provided that market rules continue to evolve [74].

\section{Effectiveness of current flexibility incentives: biogas plants}

For new biogas plants, a flexible mode of operation should in principle be ensured by the rule that funding is limited to annual electricity generation corresponding to a power rating of $50 \%$ of the installed electric capacity, as introduced in the EEG 2014. The bigger challenge is therefore setting effective incentives for existing plants to switch to flexible modes of production, if this is associated with additional costs.

The costs of realising flexibilisation potentials for existing plants depend on the future mode of operation and the general flexibilisation strategy of the plant operator. As described above, flexibilisation costs increase with a growing PQ. Lauer et al. [48] analysed the costs and the economic feasibility of different flexibilisation strategies (PQ) for two existing biogas plants. For example, the flexibilisation of one existing biogas plant with a rated power of about $800 \mathrm{~kW}$ causes additional capital-related expenses of $33,000 €$ per year for a PQ value of 1.5 , over a period of 10 years. For a PQ value of 2.1, additional capital-related expenses are estimated at $99,000-118,000 €$ per year. In order to exploit full flexibilisation potentials, comparatively high investments in additional CHP and gas storage capacities would be necessary. The optimal mode of operation and investment in components has to be calculated on the basis of the individual plant characteristics [48]. Nevertheless, Hochloff and Braun [75] show that the best economic results including the flexibility premium are achieved by using the largest CHP unit (2.0 MW) for flexible power generation from biogas plants.

To assess the number and capacity of plants which are currently capable of operating in flexible mode, the claiming of the premium payment for flexibility can be a good indicator. Information about this can be found at the "Bundesnetzagentur", especially at their "plant register", at which power generating plants based on renewables have the obligation to register (see [38]). Among the registered data, there is information about the period the plant claimed the flexibility premium for and its installed capacity. According to that, currently, there are about 2800 plants (both biogas and biomethane) receiving the payment, with about $1600 \mathrm{MW}_{\mathrm{el}}$ of installed capacity. This indicates that it has become an attractive option for plant operators (see Fig. 6). Receiving the flexibility premium does not, in and of itself, guarantee that plants are operated in a flexible mode-however, as plants have to prove their technical ability to do so, it is an indicator of the available flexibility potential. Specifically, the flexibility premium guarantees that the biogas operator has created the necessary technical conditions to generate electricity in a flexible way (e.g. additional CHP capacities). To do so, the rated capacity has to be significantly lower than the installed capacity of the biogas plant (see PQ).

Most of the plants (40\%) which receive the premium are in the range of $151-500 \mathrm{kw}_{\mathrm{el}}$, and $38 \%$ are in the 


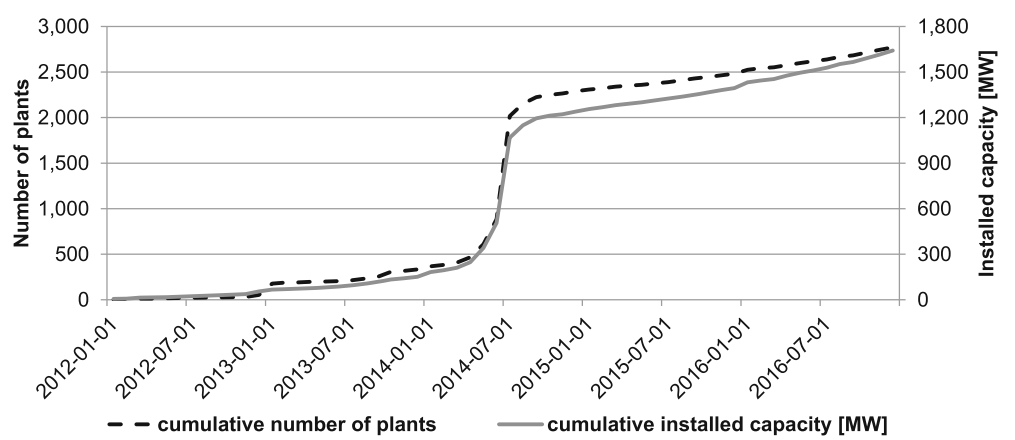

Fig. 6 Number of plants and installed capacity of biogas plants receiving the flexibility premium (source: own calculations based on [38, 125])

range of $501-1000 \mathrm{kw}_{\mathrm{el}}$. In terms of the installed electric capacity, the range of $501-1000 \mathrm{kw}_{\mathrm{el}}$ is the most relevant (46\%). Most of the registration has taken place in summer 2014 (over 1000 plants), likely in response to uncertainty about what changes would be implemented in the EEG 2014 reform.

Moreover, biogas plants are an important participant in balancing power markets; about $30 \%\left(1500 \mathrm{MW}_{\mathrm{el}}\right)$ of biogas plants were prequalified for the provision of control power in the year 2016 [76]. The majority of these provide secondary and tertiary control power, whereby a high share of the market volume, which is about $4800 \mathrm{MW}$ of positive and negative control power, can be theoretically contributed by biogas plants [77]. However, the proportion of biogas plants which contributes positive control power is still low [78]. The first plants are put on the market for primary control [79]. However, the primary control market asks for a rapid response of market players, and nowadays, this energy is provided by fossil fuel-based power plants [80]. In the future, due to their technical properties and the phase out of conventional power plants, the proportion of storage technologies in the market for primary control will increase. Consequently, participating in secondary and tertiary control power markets may prove to be a more relevant perspective for bioenergy plants; here, competitors might be vRES (for negative control power) [73], storage technologies, demand response [81] and conventional power plants.

Overall, participation in the flexibility premium scheme indicates that in general, current incentives are capable to bring about some investments in flexibility. Participation in balancing markets reflects biogas plants' contributions to grid stabilisation, but-in the case of negative control power provision at least-is not necessarily an indicator of whether or not plants are operated flexibly with regard to demand on the spot market (see above).

Besides the question of economic incentives, there may also be non-monetary obstacles which hinder a change to flexible production. The actor structure of biomass plant operators is very heterogeneous, and a large number of biogas plant operators in particular are farmers which pursue bioelectricity production as a side business. A lack of current information about energy policy developments can therefore be a relevant barrier to investments in flexible power generation from biogas plants and adjustments in production behaviour. Meanwhile, in the implementation of direct marketing, intermediaries who pool RES plants play an important role $[28,82]$. Potentially, intermediaries may be able to improve the flow of up-to-date information to plant operators.

\section{Effectiveness of current flexibility incentives: solid biomass plants}

Solid biomass plants, on the other hand, cannot claim the flexibility premium. Additional investments in flexibilisation have to be made worthwhile by the promise of higher revenues for feeding in electricity when prices are high and revenues from participation in balancing markets. Given the decreasing price volatility on the EPEX Spot SE, remuneration from participation in balancing markets plays a particularly important role.

According to a questionnaire from 2013, 29.5\% of responding solid biomass plant operators stated that they already participated in balancing markets, while 10 . $5 \%$ were preparing to do so [83]. Respondents represented 95 of 404 solid biomass CHP plants at the end of 2013 and $676 \mathrm{MW}_{\mathrm{el}}$ of an installed capacity of $1524 \mathrm{MW}_{\mathrm{el}}$ (excluding estimated increases in wood gasification plants, see [83]). All responding plants which were active in balancing markets offered negative control power, a few also positive control power. $71 \%$ worked in tertiary control, $18 \%$ in secondary control and $11 \%$ in both secondary and tertiary control. Typical control power bandwidth was between 20 and $88.5 \%$ of nominal electrical power [83].

The costs of flexibilisation once more depend on the specific technology in use. In the 2013 survey among 
solid biomass plant operators, $46 \%$ of those plants that already offered flexibility on balancing markets stated additional cost requirements of 10,000 to $50,000 €$, mainly for automation purposes [83]. Those without implemented flexibility listed mainly the following investments as necessary for taking part in the control power market [83]:

- Automation technology (5000-500,000 €)

- (Additional) heat buffer (0.1-1.2 million $€$ )

- Change to condensing operation mode (up to 10 million $€$ ).

Compared to biogas plants, which already include a gas storage facility, flexibility generally requires higher efforts. General obstacles mentioned by operators for not taking part in the control power market included (percentage of reasons named in brackets; more than one reason could be given) [83]:

- Electrical capacity of the plant not sufficient to participate in the control power market (according to the view of the surveyed owners of the systems) (21\%)

- Heat-led operation (21\%)

- Economic incentives not adequate (low remuneration for participation in balancing markets) (18\%)

- Compliance with a timeframe for provision of control power not possible (16\%)

- Unclear or complex procedure (12\%)

- Process heat needed for production processes $/ 100 \%$ of energy output is consumed by the operator (11\%).

- No request from virtual power plant operators (9\%)

Again, this shows the relevance of both monetary and non-monetary obstacles. Furthermore, in contrast to biogas plants, implementing greater flexibility in power production means a reduction in the amount of electricity produced per year, as in most cases, there are no efficient storable intermediates in the process like (cold) biogas. Therefore, to keep electricity production at the same level and to get the same amount of income from existing FIT or FIP, remuneration means installing a second CHP unit. Most likely, this second unit will not be able to receive the old remuneration rate of the existing plant but will fall under the current version of the EEG with lower remuneration rates. As a consequence, flexibilisation currently makes only sense if due to other reasons the full load hours per year are not reached anyway, e.g. because there is not enough cheap biomass supply or the fixed costs are very low due to fully refinanced investment costs.

\section{Conclusion on effectiveness of current flexibility incentives}

The previous sections show that for existing biogas plants, direct marketing in combination with flexibility premium and revenues from balancing markets incentivises some changes in production behaviour and investments in technical adjustments as well as an overhaul and expansion of plants. However, the strength of incentives is limited due to both decreasing price levels and decreasing price variance on spot markets. Moreover, balancing market developments in recent years do not give rise to the expectation that significant flexibility investments will be made worthwhile through balancing revenues only, due to increasing competition and high price volatility. This also limits incentives for investing in the flexibilisation of existing solid biomass plants, since these cannot claim the flexibility premium.

For new biogas plants, the flexibility premium and the fact that EEG remuneration is limited to the annual electricity production corresponding to a power rating of $50 \%$ of the installed electric capacity constitute effective incentives for flexible plant design and production behaviour. However, under the EEG 2014 with its decrease of remuneration rates, not much new capacity has been installed (see the "Background" section). This extreme slowdown in expansion also affects new solid biomass plants and the overall effectiveness of this measure.

Perspectives for increasing adequate flexibility incentives In combination, market and policy incentives should adequately reflect the current value and option value of flexible bioelectricity production. Adequacy, in this context, has two dimensions. First, if under current systemic and technological conditions flexible bioelectricity production has a value, it should be remunerated adequately. Second, incentives should reflect the option value of bioenergy as a flexible RES in a future electricity system. In the German debate, several market and policy reform steps are currently being discussed or implemented which affect (or may potentially affect) the remuneration of current and option values. Particularly relevant are the ongoing reform of electricity and balancing markets which alter framework conditions for all market participants, recent reforms of EEG and the Combined Heat and Power Act (Kraft-Wärme-Kopplungsgesetz-KWKG) which directly impact incentives for bioelectricity producers and the development of climate policy instruments which affect the profitability of fossil fuel-based generation capacities [84] (see Table 3). In this section, we give a brief overview of major reform options and recent policy decisions, followed by a discussion of implications for the current and option values of flexible bioelectricity provision. 
Table 3 Overview of major market and policy reform options

\begin{tabular}{|c|c|}
\hline \multirow{5}{*}{$\begin{array}{l}\text { Electricity and balancing market } \\
\text { reform }\end{array}$} & Spot market reform \\
\hline & Balancing market reform \\
\hline & $\begin{array}{l}\text { Establishment of capacity } \\
\text { mechanisms }\end{array}$ \\
\hline & $\begin{array}{l}\text { Spatial differentiation of electricity } \\
\text { prices }\end{array}$ \\
\hline & $\begin{array}{l}\text { Curtailment contracts and regional } \\
\text { flexibility markets }\end{array}$ \\
\hline \multirow{2}{*}{$\begin{array}{l}\text { Development of policy incentives } \\
\text { for bioelectricity production }\end{array}$} & Reform of EEG \\
\hline & Reform of KWKG \\
\hline \multirow{2}{*}{$\begin{array}{l}\text { Climate policy developments } \\
\text { (incentives for structural change in } \\
\text { electricity and balancing markets) }\end{array}$} & Reform of EU ETS \\
\hline & $\begin{array}{l}\text { National-level climate protection } \\
\text { measures (e.g. climate levy, plant } \\
\text { retirement) }\end{array}$ \\
\hline
\end{tabular}

\section{Electricity and balancing market reform}

Historically, spot and balancing market design has been aligned with centralised, conventional power production. As the transition to a decentralised production structure with a high share of vRES progresses, adjustments in market framework conditions become necessary to ensure a timely balancing of supply and demand and unlock flexibility potentials among all market participants. The following gives an overview of key measures which are discussed in the literature, complemented by an outlook on recent policy decisions on electricity and balancing market reform in Germany (see [84-86] for a more detailed analysis of measures). With regard to the spot market design characteristics, for instance, refraining from restrictive price boundaries and adjusting the time definition of products are considered important preconditions for price signals which incentivise flexibility in general [85-87]. Also, a further development of balancing markets can increase participation and income opportunities for flexible capacities, e.g. if the frequency of auctions is increased, bid size requirements are reduced, asymmetric bids for positive and negative reserve are permitted, or contract duration lengths are shortened [73, 74, 88]. Moreover, implementing a more stringent supervision of balancing group management and setting stronger incentives that quarter-hourly balancing actually takes place could increase remuneration for flexible capacities [89, 90].

Besides reforms that strengthen the balancing markets and the energy-only market (referred to as "EOM 2.0" in the political debate, see [85]), there is also a debate whether the large-scale expansion of vRES makes the establishment of capacity mechanisms necessary, to offer remuneration for secure generation capacities as well as storage and demand-side management options (see [91] for an overview). With an increasing feed-in from vRES with marginal costs close to zero, the merit order effect gains in strength, resulting in lower wholesale electricity prices and a decreasing load-factor of dispatchable power plants (such as gas power plants but also coal power plants [92]); this leads to concerns that dispatchable capacities may find it difficult to refinance investment costs (see [87]). In Germany, several capacity mechanism models have been debated, such as a comprehensive, centrally organised capacity market [93], a decentralised capacity market [94], a focussed capacity market which defines specific criteria to determine what capacities can participate [95], and a strategic reserve which acts as a backup for the EOM [96]. Among these models, a capacity mechanism which focusses on lowcarbon flexibility options would set the strongest incentives for flexible bioelectricity production, because in technology-neutral mechanisms, it would likely be outcompeted by conventional power plants. In a focussed mechanism, on the other hand, bioelectricity plants would compete with other technologies which fulfilled predefined flexibility and environmental criteria.

Another option for increasing flexibility incentives could be a spatial differentiation of electricity prices, e.g. through nodal pricing which would expose electricity generators to grid congestion signals when making production and location decisions $[87,97]$. Alternative remuneration mechanisms for the regional stabilisation of distribution grids are also being discussed, e.g. in the form of curtailment contracts between TSOs and power producers or consumers, or regional flexibility markets [98].

With the white paper published by the Federal Ministry for Economic Affairs and Energy (BMWi) in 2015 [85], a policy decision was made to strengthen the "EOM 2.0" and refrain from introducing capacity markets at this stage. The "electricity market law" (StrommarktG [99]) adopted in July 2016 encompasses, inter alia, a commitment to abstain from setting price caps (see [85] for an overview of measures). At the same time, it introduced a $2 \mathrm{GW}$ strategic reserve (termed "capacity reserve", $\mathbb{S} 13 \mathrm{e}$ StrommarktG) as well as a "security stand-by" for old lignite power plants which are prematurely shut down to reduce $\mathrm{CO}_{2}$ emissions but can be called upon by TSOs to safeguard security of supply ( $\$ 13 \mathrm{~g}$ StrommarktG). Participation in the capacity reserve is determined through a tendering process which is in principle technology-neutral; however, there are concerns that conditions for participation as defined in the proposed capacity reserve ordinance (\$9 KapResV draft [100]) favour conventional, fossil fuel-based power plants (e.g. installations need to be connected to a general supply grid with a rated voltage of $110 \mathrm{kV}$ or more, whereas biogas plants tend to be connected at medium voltage level) [101]. As to balancing markets, a reform of secondary and tertiary reserve market rules was adopted in 2017, to improve market 
access, e.g. for small-scale producers, demand-side management systems or storage operators [102, 103].

\section{Development of policy incentives for bioelectricity production}

To date, the EEG remains the most influential instrument for incentivising flexible bioelectricity provision. In the literature, changing the remuneration mechanism to a capacity premium has been discussed as an option to increase flexibility incentives, because unlike a feed-in premium, a capacity-based premium does not distort spot market price signals [104]. Meanwhile, the EEG 2017's change from an administered to a tendered sliding feed-in premium $[105,106]$ does not affect the premium's structural impact on production decisions as such. However, as producers have to compete for support, they may have an incentive to bid for a comparatively low reference price for the premium and place a greater emphasis on achieving high direct marketing revenues through demand-oriented feed-in and participation in balancing markets. In the first tender round in 2017, however, the competition was expected to be low, causing bids to be close to the price cap [34]. To explain low participation, industry associations pointed out that the price cap for new plants' bids was restrictive and that many existing plants would forego a higher administered EEG remuneration if they participated in the tendering scheme at this stage [107].

For future renewable energy support design, relevant questions are to what degree the flexible character of bioenergy provision should be reflected in technologyspecific remuneration levels and quantitative targets, and if so, what the temporal dimension of such a measure should be; and whether incentives set by FIP and market signals in combination are sufficient to bring about flexible plant concepts and production decisions, or whether additional incentives (such as the flexibility premium) or remuneration conditions (e.g. technical standards, power rating of 50\%) are necessary.

Moreover, the KWKG has been reformed in 2016 to, inter alia, incentivise the flexibilisation of cogeneration plants [108]. The implementation of a tendering scheme for innovative CHP systems which combine flexible CHP plants with RES-based heat production is under preparation [109]. This can provide an alternative financing mechanism for bioelectricity CHP plants besides the EEG.

\section{Climate policy developments}

In Germany, the current lack of market incentives for flexibility provision is partly due to the conventional overcapacities [110]. The BMWi estimated that in the German and European electricity market, overcapacities which are relevant for German energy supply may amount to $60 \mathrm{GW}$ ([85] based on [111, 112]). However, market adjustment processes are hindered by technological path dependencies in the electricity system, given sunk investments in long-lived and highly specialised conventional power plants [113]. Also, current emission certificate prices in the EU ETS are below what would be required to achieve climate change mitigation targets consistent with the COP21 Paris agreement, distorting price signals in favour of fossil fuel capacities [114]. The merit order effect of RES expansion reduces the profitability of conventional power plants, but the development is far from initiating a market-driven exit of coal power plants-rather, the decrease in profitability has so far mainly become a problem for peak-load gas power plants [110] which could play a complementary role to vRES. While a nuclear phase-out is being implemented until 2022 through a command and control instrument, a debate has arisen whether-beyond a reform of the EU ETS-further national-level climate protection measures are necessary to support a phase-out of coal and reach GHG emission reduction targets (for an overview, see [115]). In particular, the introduction of a "climate levy" has been discussed to change the merit order in favour of low-carbon plants, but in the end, the proposal was supplanted by the mentioned "security stand-by" which compensates selected old lignite power plants for not participating in the electricity market (see [116]). This measure will eventually take a capacity of $2.7 \mathrm{GW}$ out of the market, but it remains to be seen whether this, in combination with the progressing nuclear phase-out and a shift of further capacities from EOM to strategic reserve, will already suffice to increase wholesale electricity prices and the profitability of investments in flexible generation capacities, storage or demand-side management concepts.

\section{Implications for the remuneration of flexible bioelectricity provision}

Based on the assessment of the German case undertaken in the preceding chapters, a number of general implications regarding the current and option values of flexible bioelectricity provision and their remuneration can be derived.

The current market value of low-carbon flexibility provision in Germany is distorted by market failures The weighting of current and option value is likely to differ depending on the country- and electricity systemspecific framework conditions. In Germany, spot market and balancing market signals indicate no pressing demand for additional flexibility provision at present. However, as discussed above, the presence of technological path dependencies and lack of stringent climate policy framework conditions limit incentives for structural 
change. Adapting electricity and balancing market rules to the needs of the energy transition is an important precondition to allow the full value of flexibility provision to be expressed in markets, but stronger market signals for flexibility are only to be expected once the expansion of vRES progresses and nuclear and fossil capacities are further reduced. This means that in the present German context, the option value of low-carbon flexibility provision is particularly important.

Market incentives alone are unlikely to adequately remunerate the option value of innovative low-carbon flexibility options In principle, reliable carbon price signals and a credible strategic commitment to the energy transition could give rise to expectations that investments in innovative low-carbon flexibility options will prove profitable in the future; however, uncertainty about future carbon price and electricity market price developments dampen incentives for such search efforts. Moreover, insufficiently internalised climate change externalities interact with knowledge and learning spillovers which are associated with investing in and using innovative flexibility options and constitute positive externalities. This interaction implies that investments in innovative, environmentally beneficial technologies tend to be lower than optimal from a social perspective [117]. As a result, it can be beneficial to include instruments directed at technology diffusion in the policy mix, beyond improved carbon pricing and R\&D support [118-120]. In the German context, examples would be incentives for flexible RES or RES-based storage options as part of the EEG, incentives for flexible CHP plants as part of the KWKG or instruments which support or facilitate the implementation of demand response management. Also, a focussed capacity mechanism could be used to remunerate the option value of low-carbon flexibility options. However, implementing a new capacity mechanism would not only be associated with transaction costs but also with risks of market distortions when interacting with the EOM; so far, the need for additional capacity mechanisms is discussed contentiously in the literature (see $[84,91]$ for an overview). In this context, it may be advantageous-and also easier to implement politically-to first of all continue to develop flexibility incentives for low carbon options in existing instruments such as the EEG and KWKG.

If bioelectricity is supported because of its option value, tying remuneration to flexibility requirements remains necessary Bioelectricity represents one technology among a range of flexibility options, and it is yet unclear which ones will prove competitive in the future-in other words, the economic potential of flexible bioelectricity provision is yet to be determined. A support scheme that is technology-neutral with reference to low-carbon technologies, such as a focussed capacity market, would favour statically cost-effective options, but not necessarily the development of a portfolio of flexibility options including bioelectricity. Technologyspecific support for selected flexibility options, on the other hand, can be subject to the problems associated with "picking winners", such as the risk of costly steering errors. In Germany, the option value is to date reflected through measures with a comparatively high degree of technology specificity, such as flexibility premium, the requirement of having a PQ of at least 2 and technical requirements for biogas plants. In principle, highly specific requirements bear the risk that plant operators may optimise plant concepts according to EEG remuneration rules rather than choose the most efficient concept based on what information is available to them decentrally (for example, when it comes to settling on a PQ value or decisions about a power vs. heat led operation). However, if the rationale for supporting bioelectricity as a comparatively costly RES technology is based on its option value as a flexibility option, specific flexibility requirements are necessary to incentivise the development and use of technological and organisational innovations needed for flexibility provision. In part, this necessity for specific flexibility rules derives from the structure of market premium incentives-receiving the market premium is tied to actual feed-in, so that in absence of the requirement of having a $\mathrm{PQ}$ of at least 2 , bioelectricity producers have an incentive to feed-in electricity even in times of low electricity prices, as long as the sum of electricity price and expected market premium is above marginal production costs [68]. As a potential alternative to production-based support, a capacity-based premium distorts market signals less [104]; however, it may bring about new distortions in investment decisions, by incentivising a maximisation of capacity without regard for "optimal" PQ value. In the end, a careful balancing is necessary when determining the degree of specificity of remuneration rules; care should be taken not to exclude alternative environmentally beneficial and economically feasible forms of bioelectricity provision, such as concepts with a high co-production of heat. Potentially, flexibility incentives can also be strengthened by further developing different income opportunities besides the EEG, e.g. in the context of regional flexibility markets [98] or the provision of ancillary services [39].

The market potential of flexible bioelectricity provision depends on the level of remuneration-but reflecting the option value does not equal supporting flexibility no matter the price At present, the market potential of flexible bioelectricity provision is strongly dependent on policy incentives. In the German case, the EEG 2014 severely reduced bioelectricity remuneration rates, primarily 
because of concerns about technology and support costs [29]. With technology-specific support, this kind of reevaluation and deselection of technologies needs to take place; even though in the case of bioelectricity, the step can be criticised with regard to its option value as the main dRES (with little potential for a further expansion of water power). Nonetheless, the costs of remunerating bioelectricity's option value are borne by electricity consumers, via the EEG surcharge. With its increased expansion target and higher price caps compared to the EEG 2014's administered remuneration rates, the EEG 2017 seems better suited to reflect the option value in principle; at the same time, the tendering scheme offers a framework for identifying the most cost-effective solutions for flexible bioelectricity provision among existing and new plants. After the first tender round, the scheme's lack of attractiveness for existing plants emerges as a problem, although this is likely to change as plants get closer to the end of their guaranteed remuneration period. For new plants, an assessment is necessary whether price caps should be adjusted, given that a certain critical mass of new plant realisation would be necessary for achieving learning effects. However, if sufficient competition cannot be guaranteed, plants will continue to bid close to the permissible maximum, negating the tendering scheme's advantages compared to an administered remuneration. This is particularly problematic as tenders are held only annually, with unused tender volumes added to the subsequent round ( $\$ 28$ (3) and (3a) EEG 2017). This limits opportunities to adjust the bidding scheme's design in a gradual learning process. With a comparatively restrictive support for new and existing plants, it is expected that total installed electric capacity of biomass plants will start to decrease by the early to mid-2020s, as the shutdown of old plants will come to dominate the installation of new capacities [121]. Depending on future policy developments, this could limit potential systemic contributions of flexible bioelectricity production significantly.

\section{Conclusions}

An assessment of technical potentials and systemic contributions shows that bioelectricity can in principle be a well-suited option to provide flexibility for grid stabilisation and residual load balancing. To allow for flexible production, biogas plants require an increase of nominal power over rated power. With solid biomass plants, the technical flexibilisation potential depends more strongly on the specific technologies used. Fast responses can be implemented with small-scale CHP systems which are a promising future option for flexibility provision from solid biomass. Meanwhile, even if the technical potential of flexible bioelectricity provision is high, the economic potential is decisive for whether bioelectricity will prove a cost-effective flexibility option in the future electricity system. As this depends on the long-term competitiveness (in terms of full social costs) with other innovative low-carbon flexibility options, the economic potential is as yet uncertain. More immediately, the market potential is determined by what remuneration can be realised in the spot and balancing markets and under policy support schemes. To date, the current market value of additional flexibility provision by low-carbon options is low. However, in combination, the EEG's flexibility premium and the opportunity to achieve revenues in balancing markets when participating in direct marketing have caused a growing number of existing biogas plants to implement adjustments allowing for a flexible production mode. Meanwhile, few new plants have been realised under the EEG 2014, and the EEG 2017 does not appear to change this trend so far.

Against this background, it is important to take the option value of flexible bioelectricity production into account when further developing policy incentives. The option value reflects the dynamic cost advantages of keeping bioelectricity in the technology mix until more is known about its long-term competitiveness as a flexibility provision option. Breaking off technology development now and picking it up later will come at an added cost, because of negative impacts on investor confidence and an acceleration of knowledge depreciation rates [118]. Frequent policy changes in particular may lead to a high degree of uncertainty for market actors, making them unwilling to undertake investments unless payback periods are very short (as pointed out by Eucken, who emphasised the importance of continuity in economic policy [122]). A "stop-and-go" pattern of support should therefore be avoided. Furthermore, planning security could be improved by an updated bioenergy strategy which clearly outlined conditions and cornerstones of future bioenergy policy; this would help research and industry to develop appropriate, competitive technologies for the future energy system.

Meanwhile, a decision about whether to continue support for bioelectricity production should not be based on static cost-effectiveness considerations alone-especially if such an evaluation is based on comparing bioelectricity's generation costs with the vRES wind and solar, the former's option value for flexibility provision may be overlooked. To maintain this option value, there is a case for setting policy incentives in a way that a continued technological development remains possible, until there is more information about flexibility requirements of future power systems as well as about the availability and costs of alternative low-carbon flexibility options (e.g. storage systems, demand response).

Finally, to enable the option value of low-carbon flexibility provision to eventually translate into a current value, complementary policies are necessary to support 
structural change in the energy sector. In particular, a stringent climate policy framework has an important role to play in reducing the amount of conventional overcapacities in the system, which would contribute to more effective market incentives for low-carbon flexibility provision.

\section{Endnotes}

${ }^{1}$ Hydropower represents another mature RES technology which is less volatile than wind or PV [4], but in Germany, there is little potential for further expansion [2].

${ }^{2}$ Under the EEG 2014, higher reference prices apply for biogas plants based primarily on organic waste or slurry ( $\$ 45$ and 46 EEG 2014); the EEG 2017 maintains comparatively high administered remuneration rates for small slurry-based biogas plants (\$44 EEG 2017).

${ }^{3}$ Calculated according to today's heat use from biomass, estimating lower capacities but a higher number of installations in the future consuming more or less the same amount of solid biofuels.

${ }^{4}$ Decreasing spot market price levels also affect the profitability of natural gas power plants as an established flexibility options; moreover, the increasing market penetration of vRES decreases plants' full load hours [92]. Meanwhile, gas power plants' profitability is also strongly affected by coal and natural gas price developments; from the end of 2015, a decreasing price spread between gas and coal improved gas power plants' competitiveness compared to hard coal power plants [126, 127].

\section{Acknowledgements}

Joint research on this paper has been undertaken in the context of the UFZ Integrated Project (IP) "EnergyLandUse" in cooperation with the DBFZ. Further information can be found at http://www.ufz.de/energylanduse. We would like to thank the three anonymous reviewers for their valuable comments.

\section{Funding}

This research received general funding from the Helmholtz Association of German Research Centres and the Federal Ministry of Food and Agriculture (BMEL). The funding bodies had no impact on the design of the study, data interpretation or the writing of the manuscript.

\section{Availability of data and materials}

For data used in the compilations of figures or as support for statements in the text, sources are given in the text or figure captions. No original data was collected for this article. Links to publicly available data can be found in the list of references.

\section{Authors' contributions}

Several authors drafted the different parts of the first version of this manuscript. All authors contributed to the revising and finalising of the article. All authors read and approved the final manuscript.

\section{Competing interests}

The authors declare that they have no competing interests.

\section{Publisher's Note}

Springer Nature remains neutral with regard to jurisdictional claims in published maps and institutional affiliations.

\section{Author details}

${ }^{1}$ Department of Economics, Helmholtz Centre for Environmental Research UFZ, Permoserstr. 15, 04318 Leipzig, Germany. ${ }^{2}$ DBFZ Deutsches Biomasseforschungszentrum, Torgauer Str. 116, 04347 Leipzig, Germany. ${ }^{3}$ Department of Bioenergy, Helmholtz Centre for Environmental Research UFZ, Permoserstr, 15, 04318 Leipzig, Germany. ${ }^{4}$ Institute for Infrastructure and Resources Management, University of Leipzig, Grimmaische Str. 12, 04109 Leipzig, Germany. ${ }^{5}$ Department of Engineering and Natural Sciences, Hochschule Merseburg (University of Applied Sciences), Eberhard-Leibnitz-Straße 2, 06217 Merseburg, Germany.

Received: 11 October 2017 Accepted: 4 April 2018

Published online: 14 May 2018

\section{References}

1. BMWi [Federal Ministry for Economic Affairs and Energy] (2014) Zweiter Monitoring-Bericht "Energie der Zukunft". BMWi, Berlin

2. Nitsch J, Pregger T, Naegler T, Heide D, de Tena DL, Trieb F, Scholz Y, Nienhaus K, Gerhardt N, Sterner M, Trost T, von Oehsen A, Schwinn R, Pape C, Hahn H, Wickert M, Wenzel B (2012) Langfristszenarien und Strategien für den Ausbau der erneuerbaren Energien in Deutschland bei Berücksichtigung der Entwicklung in Europa und global. Deutsches Zentrum für Luft- und Raumfahrt (DLR), Fraunhofer Institut für Windenergie und Energiesystemtechnik (IWES), Ingenieurbüro für neue Energien (IFNE), Stuttgart, Kassel, Teltow

3. IEA (2008) Empowering variable renewables. Options for flexible electricity systems. In support of the G8 Plan of Action. IEA, OECD, Paris

4. Häseler S (2014) Procuring flexibility to support Germany's renewables: policy options. Z Energiewirtsch 38(3):151-162. https://doi.org/10.1007/s12398-014-0128-x

5. Leprich U, Hauser E, Grashof K, Grote L, Luxenburger M, Sabatier M, Zipp A (2012) Kompassstudie Marktdesign. Leitideen für ein Design eines Stromsystems mit hohem Anteil fluktuierender Erneuerbarer Energien. Ein Projekt der BEE-Plattform Systemtransformation. Ponte Press, Bochum

6. Gatzen C, Riechmann C (2011) Stationäre Stromspeicher - zukünftiger Nischenmarkt oder Milliardengeschäft? Energiewirtschaftliche Tagesfragen 61(3):20-23

7. Pape C, Gerhardt N, Härtel P, Scholz A, Schwinn R, Drees T, Maaz A, Sprey J, Breuer C, Moser A, Sailer F, Reuter S, Müller T (2014) Roadmap Speicher. Bestimmung des Speicherbedarfs in Deutschland im europäischen Kontext und Ableitung von technisch-ökonomischen sowie rechtlichen Handlungsempfehlungen für die Speicherförderung. Endbericht. Fraunhofer-Institut für Windenergie und Energiesystemtechnik (IWES), Fraunhofer Institut für Elektrische Anlagen und Energiewirtschaft (IAEW), Stiftung Umweltenergierecht, Kassel, Aachen, Würzburg

8. Gils HC (2014) Assessment of the theoretical demand response potential in Europe. Energy 67:1-18. https://doi.org/10.1016/j.energy.2014.02.019

9. Deutsche Energieagentur (dena) (2010) Grid study II. Integration of renewable energy sources in the German power supply system from 20152020 with an outlook to 2025. dena, Berlin

10. Szarka N, Scholwin F, Trommler M, Fabian Jacobi H, Eichhorn M, Ortwein A, Thrän D (2013) A novel role for bioenergy: a flexible, demand-oriented power supply. Energy 61:18-26. https://doi.org/10.1016/j.energy.2012.12.053

11. Thrän D, Dotzauer M, Lenz V, Liebetrau J, Ortwein A (2015) Flexible bioenergy supply for balancing fluctuating renewables in the heat and power sector - a review of technologies and concepts. Energy, Sustainability and Society 5(1):35. https://doi.org/10.1186/s13705-015-0062-8

12. Thrän D, Scholwin F, Witt J, Krautz A, Bienert K, Hennig C, Rensberg N, Stinner W, Schaubach K, Gawor M, Trommler M, Grope J, Daniel-Gromke J, Richarz V, Naumann K, Viehmann C, Majer S, Schwenker A, Billig E, Wirkner R, Lenz V (2011) Vorbereitung und Begleitung der Erstellung des Erfahrungsberichtes 2011 gemäß § 65 EEG im Auftrag des Bundesministeriums für Umwelt, Naturschutz und Reaktorsicherheit. Vorhaben lla. Endbericht. Deutsches Biomasseforschungszentrum (DBFZ), Leipzig

13. Kost C, Mayer JN, Thomsen J, Hartmann N, Senkpiel C, Philipps S, Nold S, Lude S, Schlegl T (2013) Stromgestehungskosten Erneuerbare Energien. Fraunhofer-Institut für Solare Energiesysteme ISE, Freiburg

14. Weisbrod BA (1964) Collective-consumption services of individualconsumption goods. Q J Econ 78(3):471-477. https://doi.org/10.2307/1879478

15. Papaefthymiou G, Grave K, Dragoon K (2014) Flexibility options in electricity systems. Project number: POWDE14426, by order of: European Copper Institute. Ecofys, Berlin 
16. Peek M, Diels R (2016) Strommarktdesign der Zukunft. Climate Change, 20/ 2015. Umweltbundesamt (UBA), Dessau-Roßlau

17. Jülch V (2016) Comparison of electricity storage options using levelized cost of storage (LCOS) method. Appl Energy 183:1594-1606. https://doi.org/10.1016/j.apenergy.2016.08.165

18. Lund PD, Lindgren J, Mikkola J, Salpakari J (2015) Review of energy system flexibility measures to enable high levels of variable renewable electricity. Renew Sust Energ Rev 45:785-807. https://doi.org/10.1016/j.rser.2015.01.057

19. Krzikalla N, Achner S, Brühl S (2013) Möglichkeiten zum Ausgleich fluktuierender Einspeisungen aus Erneuerbaren Energien. Studie im Auftrag des Bundesverbandes Erneuerbare Energie. BET Büro für Energiewirtschaft und technische Planung $\mathrm{GmbH}$, Aachen

20. Michaelis J, Eichhammer W, Marwitz S, Wietschel M (2016) Flexible energy system building blocks. Reader for the participants of: Transregional Workshop on Solar Power Plants, 12th of October 2016, Abu Dhabi, hosted by BMUB with support of GIZ. Fraunhofer Institute for Systems and Innovation Research ISI, Karlsruhe

21. Denholm P, Hand M (2011) Grid flexibility and storage required to achieve very high penetration of variable renewable electricity. Energy Policy 39(3): 1817-1830. https://doi.org/10.1016/j.enpol.2011.01.019

22. Huber M, Dimkova D, Hamacher T (2014) Integration of wind and solar power in Europe: assessment of flexibility requirements. Energy 69:236-246. https://doi.org/10.1016/j.energy.2014.02.109

23. Kondziella $H$, Bruckner T (2016) Flexibility requirements of renewable energy based electricity systems-a review of research results and methodologies. Renew Sust Energ Rev 53:10-22. https://doi.org/10.1016/j.rser.2015.07.199

24. UBA [Federal Environment Agency] (2017) Erneuerbare Energien in Deutschland. Daten zur Entwicklung im Jahr 2016. UBA, Dessau-Roßlau

25. Scheftelowitz M, Daniel-Gromke J, Denysenko V, Hillebrand K, Krautz A, Lenz V, Liebetrau J, Naumann K, Ortwein A, Rensberg N, Stinner W, Trommler M, Barchmann T, Witt J, Zeymer M, Schaubach K, Büchner D, Thrän D, Peters W, Schicketanz S, Schultze C, Deumelandt P, Reinicke F, Gröber H, Beil M, Beyrich W (2014) Vorbereitung und Begleitung der Erstellung des Erfahrungsberichts 2014 gemäß § 65 EEG im Auftrag des Bundesministeriums für Wirtschaft und Energie. Vorhaben lla: Stromerzeugung aus Biomasse. Deutsches Biomasseforschungszentrum (DBFZ), Helmholtz-Zentrum für Umweltforschung -UFZ, Bosch \& Partner, Privates Institut für Nachhaltige Landbewirtschaftung (INL), Fraunhofer-Institut für Windenergie und Energiesystemtechnik (IWES), Leipzig

26. Purkus A (2016) Concepts and instruments for a rational bioenergy policy. A new institutional economics approach. Lecture notes in energy volume 55. Springer International Publishing, Cham

27. Klobasa M, Winkler J, Sensfuß F, Ragwitz M (2013) Market integration of renewable electricity generation-the German market premium model. Energy \& Environment 24(1-2):127-146. https://doi.org/10.1260/0958-305X.24.1-2.127

28. Purkus A, Gawel E, Deissenroth M, Nienhaus K, Wassermann S (2015) Market integration of renewable energies through direct marketing-lessons learned from the German market premium scheme. Energy, Sustainability and Society 5(1):12. https://doi.org/10.1186/s13705-015-0040-1

29. Bundestag (2014) Drucksache des Deutschen Bundestages 18/1304 vom 05. 05.2014: Entwurf eines Gesetzes zur grundlegenden Reform des Erneuerbare-Energien-Gesetzes und zur Änderung weiterer Bestimmungen des Energiewirtschaftsrechts. Bundestag, Berlin

30. Thrän D, Krautz A, Scheftelowitz M, Lenz V, Liebetrau J, Daniel-Gromke J, Zeymer M, Nelles M (2014) Auswirkungen der gegenwärtig diskutierten Novellierungsvorschläge für das EEG-2014. Deutsches Biomasseforschungszentrum (DBFZ), Leipzig

31. Bundesrat (2016) Drucksache des Bundesrates 355/16 vom 08.07.2016. Gesetzesbeschluss des Deutschen Bundestages. Gesetz zur Einführung von Ausschreibungen für Strom aus erneuerbaren Energien und zu weiteren Änderungen des Rechts der erneuerbaren Energien. Bundesrat, Berlin

32. Bundesrat (2016) Drucksache des Bundesrates 310/16 vom 09.06.2016. Gesetzentwurf der Bundesregierung. Entwurf eines Gesetzes zur Einführung von Ausschreibungen für Strom aus erneuerbaren Energien und zu weiteren Änderungen des Rechts der erneuerbaren Energien (ErneuerbareEnergien-Gesetz - EEG 2016). Bundesrat, Berlin

33. EEG 2017 Erneuerbare-Energien-Gesetz vom 21. Juli 2014 (BGBI. I S. 1066), das zuletzt durch Artikel 2 des Gesetzes vom 22. Dezember 2016 (BGBI. I S. 3106) geändert worden ist.

34. Bundesnetzagentur (2017) Ergebnisse der ersten Ausschreibung für Biomasse. Pressemitteilung. https://www.bundesnetzagentur.de/
SharedDocs/Pressemitteilungen/DE/2017/18092017_Biomasse.html?nn= 265778. Accessed 21 Sept 2017.

35. BMWi [Federal Ministry for Economic Affairs and Energy], AGEE-Stat [Working Group on Renewable Energy Statistics] (2017) Zeitreihen zur Entwicklung der erneuerbaren Energien in Deutschland unter Verwendung von Daten der Arbeitsgruppe Erneuerbare Energien-Statistik (AGEE-Stat) (Stand: Februar 2017). https://www.erneuerbare-energien.de/EE/Navigation/ DE/Service/Erneuerbare_Energien_in_Zahlen/Zeitreihen/zeitreihen.html. Accessed 27 June 2017.

36. Lenz V, Müller-Langer F, Denysenko V, Daniel-Gromke J, Reinsberg N, Rönsch C, Janczik S, Kaltschmitt M (2017) Erneuerbare Energien. BWK Energie-Fachmagazin 69(5):54-77

37. Scheftelowitz M, Rensberg N, Denysenko V, Daniel-Gromke J, Stinner W, Hillebrand K, Naumann K, Peetz D, Hennig C, Thrän D, Beil M, Kasten J, Vogel L (2015) Stromerzeugung aus Biomasse (Vorhaben lla Biomasse). Zwischenbericht Mai 2015. Bericht im Auftrag des Bundesministeriums für Wirtschaft und Energie (BMWi). Deutsches Biomasseforschungszentrum (DBFZ) Helmholtz-Zentrum für Umweltforschung - UFZ, Fraunhofer - Institut für Windenergie und Energiesystemtechnik (IWES), Bosch \& Partner, Leipzig

38. Bundesnetzagentur (2017) Veröffentlichung der im Anlagenregister registrierten Daten. Stand April 2017. https://www.bundesnetzagentur.de/ DE/Sachgebiete/ElektrizitaetundGas/Unternehmen_Institutionen/ ErneuerbareEnergien/Anlagenregister/Anlagenregister_node.html. Accessed 27 June 2017.

39. Hauser E, Wern B (2016) The role of bioenergy in the German "Energiewende" - whose demands can be satisfied by bioenergy? Energy, Sustainability and Society 6(1):35. https://doi.org/10.1186/s13705-016-0101-0

40. Huber M, Weissbart C (2015) On the optimal mix of wind and solar generation in the future Chinese power system. Energy 90:235-243. https://doi.org/10.1016/j.energy.2015.05.146

41. Tafarte P, Das S, Eichhorn M, Dotzauer M, Thrän D (2015) The potential of flexible power generation from biomass: a case study for a German region. In: Thrän D (ed) Smart bioenergy. Technologies and concepts for a more flexible bioenergy provision in future energy systems. Springer International Publishing, Cham, pp 141-159

42. IPCC (2011) Special report on renewable energy sources and climate change mitigation. Cambridge University Press, United Kingdom and New York

43. Agentur für Erneuerbare Energien (AEE) (2013) Studienvergleich: Entwicklung der Stromgroßhandels- und der $\mathrm{CO}_{2}$-Zertifikatspreise. Berlin

44. Ketterer JC (2014) The impact of wind power generation on the electricity price in Germany. Energy Econ 44:270-280 https://doi.org/10.1016/j.eneco. 2014.04.003

45. Energy Brainpool (2016) Energy BrainReport 2016 - Sicherheitsbereitschaft hat kaum Auswirkungen auf Strompreise. https://www.energybrainpool. com/news-details/datum/2016/02/04/energy-brainreport-2016sicherheitsbereitschaft-hat-kaum-auswirkungen-auf-strompreise.html. Accessed 05 Feb 2018.

46. Brosowski A, Thrän D, Mantau U, Mahro B, Erdmann G, Adler P, Stinner W, Reinhold G, Hering T, Blanke C (2016) A review of biomass potential and current utilisation - status quo for 93 biogenic wastes and residues in Germany. Biomass Bioenergy 95:257-272. https://doi.org/10.1016/j.biombioe. 2016.10.017

47. Hennig C, Brosowski A, Majer S (2016) Sustainable feedstock potential-a limitation for the bio-based economy? J Clean Prod 123:200-202. https:// doi.org/10.1016/j.jclepro.2015.06.130

48. Lauer M, Dotzauer M, Hennig C, Lehmann M, Nebel E, Postel J, Szarka N, Thrän D (2017) Flexible power generation scenarios for biogas plants operated in Germany: impacts on economic viability and GHG emissions. Int J Energy Res 41(1):63-80. https://doi.org/10.1002/er.3592

49. Ortwein $A$, Lenz $\vee(2015)$ Flexible power generation from solid biofuels. In: Thrän D (ed) Smart bioenergy. Technologies and concepts for a more flexible bioenergy provision in future energy systems. Springer International Publishing Switzerland, pp 49-66

50. Sanner B, Angelino L, De Gregorio M, Février N, Haslinger W, Kujbus A, Landolina S, Sparber W, Stryi-Hipp G, van Helden W, Weiss W (2013) Strategic research and innovation agenda for renewable heating \& cooling. European Technology Platform on Renewable Heating and Cooling, Brussels

51. Baur F, Noll F, Vogler C, Wern B, Mees M, Steinert M, Wiedemeyer N, Beyer S, Hill A, Gebauer M, Pauschinger T, Kornmann A, Menke C, Barton M (2016) Wärmestudie Region Eifel und Trier. Studie im Auftrag des Ministeriums für Wirtschaft, Klimaschutz, Energie und Landesplanung des Landes Rheinland- 
Pfalz. IZES, SWT Stadtwerke Trier, Energieagentur Region Trier, Ecoscop, Solites, Hochschule Trier, Saarbrücken

52. BMWi [Federal Ministry for Economic Affairs and Energy] (2017) Ergebnispapier Strom 2030 - Langfristige Trends. Aufgaben für die kommenden Jahre, Berlin

53. Thrän D, Pfeiffer D (eds) (2015) Meilensteine 2030. Elemente und Meilensteine für die Entwicklung einer tragfähigen und nachhaltigen Bioenergiestrategie. Schriftenreihe des Förderprogramms "Energetische Biomassenutzung" Band 18. Deutsches Biomasseforschungszentrum (DBFZ), Leipzig

54. Schill W-P (2014) Residual load, renewable surplus generation and storage requirements in Germany. Energy Policy 73:65-79. https://doi.org/10.1016/j. enpol.2014.05.032

55. Hirth L, Müller S (2016) System-friendly wind power. Energy Econ 56:51-63. https://doi.org/10.1016/j.eneco.2016.02.016

56. Tafarte P, Buck P (2017) Integration of wind power-challenges and options for market integration and its impact on future cross-sectorial use, Paper presented at the 14th International Conference on the European Energy Market (EEM), Technische Universität Dresden, Dresden, 6-9 June 2017

57. Tafarte P, Das S, Eichhorn M, Thrän D (2014) Small adaptations, big impacts: options for an optimized mix of variable renewable energy sources. Energy 72:80-92. https://doi.org/10.1016/j.energy.2014.04.094

58. Becker S, Frew BA, Andresen GB, Jacobson MZ, Schramm S, Greiner M (2015) Renewable build-up pathways for the US: generation costs are not system costs. Energy 81:437-445. https://doi.org/10.1016/j.energy.2014.12.056

59. Solomon AA, Kammen DM, Callaway D (2016) Investigating the impact of wind-solar complementarities on energy storage requirement and the corresponding supply reliability criteria. Appl Energy 168:130-145. https://doi.org/10.1016/j.apenergy.2016.01.070

60. Mills AD, Wiser RH (2015) Strategies to mitigate declines in the economic value of wind and solar at high penetration in California. Appl Energy 147: 269-278. https://doi.org/10.1016/j.apenergy.2015.03.014

61. Lauer M, Röppischer P, Thrän D (2017) Flexible biogas plants as servant for power provision systems with high shares of renewables: contributions to the reduction of the residual load in Germany. Paper presented at the EUBCE, Stockholm, pp 12-15

62. Tafarte $P$, Hennig C, Dotzauer M, Thrän D (2017) Impact of flexible bioenergy provision on residual load fluctuation: a case study for the TransnetBW transmission system in 2022. Energy, Sustainability and Society 7(1):3. https://doi.org/10.1186/s13705-017-0108-1

63. Ueckerdt F, Brecha R, Luderer $G$ (2015) Analyzing major challenges of wind and solar variability in power systems. Renew Energy 81:1-10. https://doi. org/10.1016/j.renene.2015.03.002.

64. Schlachtberger DP, Becker S, Schramm S, Greiner M (2016) Backup flexibility classes in emerging large-scale renewable electricity systems. Energy Convers Manag 125:336-346. https://doi.org/10.1016/..enconman.2016.04.020

65. Sterner M (2009) Bioenergy and renewable power methane in integrated 100\% renewable energy systems_-limiting global warming by transforming energy systems. Vol 14. Kassel University Press, Kassel

66. Trommler M, Barchmann T, Dotzauer M, Cieleit A (2017) Can biogas plants contribute to lower the demand for power grid expansion? Chemical Engineering \& Technology 40(2):359-366. https://doi.org/10.1002/ceat. 201600230

67. Szarka N, Eichhorn M, Kittler R, Bezama A, Thrän D (2017) Interpreting longterm energy scenarios and the role of bioenergy in Germany. Renew Sust Energ Rev 68:1222-1233. https://doi.org/10.1016/j.rser.2016.02.016

68. Gawel E, Purkus A (2013) Promoting the market and system integration of renewable energies through premium schemes-a case study of the German market premium. Energy Policy 61:599-609. https://doi.org/10.1016/ j.enpol.2013.06.117

69. Tascikaraoglu A, Erdinc O, Uzunoglu M, Karakas A (2014) An adaptive load dispatching and forecasting strategy for a virtual power plant including renewable energy conversion units. Appl Energy 119:445-453. https://doi. org/10.1016/j.apenergy.2014.01.020

70. Scheftelowitz M, Becker $R$, Thrän D (2018) Improved power provision from biomass: A retrospective on the impacts of German energy policy. Biomass and Bioenergy 111:1-12

71. Nicolosi M, Fürsch M (2009) The impact of an increasing share of RES-E on the conventional power market-the example of Germany. Z Energiewirtsch 33(3):246-254. https://doi.org/10.1007/s12398-009-0030-0
72. Bundesnetzagentur (2018) Regelenergie. https:/www.bundesnetzagentur. de/DE/Sachgebiete/ElektrizitaetundGas/Unternehmen_Institutionen/ Versorgungssicherheit/Engpassmanagement/Regelenergie/regelenergienode.html. Accessed 15 April 2018

73. Hirth L, Ziegenhagen I (2015) Balancing power and variable renewables: three links. Renew Sust Energ Rev 50:1035-1051. https://doi.org/10.1016/j. rser.2015.04.180

74. Borne O, Korte K, Perez Y, Petit M, Purkus A (2018) Barriers to entry in frequency-regulation services markets: review of the status quo and options for improvements. Renew Sust Energ Rev 81:605-614 https://doi.org/10. 1016/j.rser.2017.08.052

75. Hochloff P, Braun M (2014) Optimizing biogas plants with excess power unit and storage capacity in electricity and control reserve markets. Biomass Bioenergy 65:125-135. https://doi.org/10.1016/j.biombioe.2013.12.012

76. Holzhammer U, Krautkremer B, Jentsch M, Kasten J (2016) Beitrag von Biogas zu einer verlässlichen erneuerbaren Stromerzeugung. Fraunhofer Institut für Windenergie und Energiesystemtechnik (IWES), Kassel

77. Clean Energy Sourcing (Clens) (2014) Stand und Perspektiven der Regelenergievermarktung durch Biogasanlagen, 15. NRW-Biogastagung. http:// www.clens.eu/fileadmin/Daten/Mediathek/Termine/140327_Stand_Perspektiven_ Regelenergie_mit_BGA_Kraft_gehalten.pdf. Accessed 27 June 2017.

78. Keymer U, Ikenmeyer K (2014) Direktvermarktung II - Regelleistung. Biogas Forum Bayern Nr. V - 18/2014. ALB Bayern e.V., Freising

79. Energy2market $\mathrm{GmbH}$ (e2m) (2014) Freie Wahl am Regelenergiemarkt - e2m vermarktet Primärregelleistung. http://www.energy2market.com/108. html?\&tx_ttnews\%5Bpointer\%5D=3\&tx_ttnews\%5BbackPid\%5D=153\&tx_ ttnews\%5Btt_news\%5D=232\&cHash=83699d8a43cla5bbe632ccc46588d0dd. Accessed 27 June 2017.

80. Forschungsgemeinschaft für Elektrische Anlagen und Stromwirtschaft (FGH) e.V, Consulting für Energiewirtschaft und -technik GmbH (CONSENTEC), Institut für Elektrische Anlagen und Stromwirtschaft (IAEW) der RWTH Aachen (2012) Studie zur Ermittlung der technischen Mindesterzeugung des konventionellen Kraftwerksparks zur Gewährleistung der Systemstabilität in den deutschen Übertragungsnetzen bei hoher Einspeisung erneuerbarer Energien. Studie im Auftrag der deutschen Übertragungsnetzbetreiber, Aachen

81. Heydarian-Forushani E, Golshan MEH, Shafie-khah M, Catalão JPS (2015) Optimal behavior of demand response aggregators in providing balancing and ancillary services in renewable-based power systems. In: CamarinhaMatos L, Baldissera T, Di Orio G, Marques F (eds) Technological innovation for cloud-based engineering systems. Springer International Publishing, Cham, pp 309-316

82. Wassermann S, Reeg M, Nienhaus K (2015) Current challenges of Germany's energy transition project and competing strategies of challengers and incumbents: the case of direct marketing of electricity from renewable energy sources. Energy Policy 76:66-75. https://doi.org/10.1016/.enpol.2014.10.013

83. Lehmann S (2014) Auswertung "Fragebogen bezüglich technischer Anforderungen an Biomasse(heiz)kraftwerke für die Beteiligung am Regelenergiemarkt". In: Nelles M (ed) Tagungsband "DBFZ-Jahrestagung 1.-2. Oktober 2014". Deutsches Biomasseforschungszentrum (DBFZ), Leipzig, pp 88-96

84. Reeg M, Brandt R, Gawel E, Heim S, Korte K, Lehmann P, Massier P, Schober D, Wassermann S (2015) Kapazitätsmechanismen als Rettungsschirm der Energiewende? Zur Versorgungssicherheit bei hohen Anteilen fluktuierender erneuerbarer Energien im Stromsystem. Discussion Paper 01/ 15. Helmholtz-Allianz ENERGY-TRANS, Leipzig

85. BMWi [Federal Ministry for Economic Affairs and Energy] (2015) An electricity market for Germany's energy transition. White Paper, Berlin

86. IEA Renewable Energy Technology Deployment Technology Collaboration Programme (IEA RETD TCP) (2016) Electricity market design and RE deployment (RES-E-MARKETS). IEA RETD TCP, Utrecht

87. Henriot A, Glachant JM (2013) Melting-pots and salad bowls: the current debate on electricity market design for integration of intermittent RES. Util Policy 27:57-64. https://doi.org/10.1016/j.jup.2013.09.001

88. Eid C, Codani P, Perez Y, Reneses J, Hakvoort R (2016) Managing electric flexibility from distributed energy resources: a review of incentives for market design. Renew Sust Energ Rev 64:237-247. https://doi.org/10.1016/j. rser.2016.06.008

89. Heim S, Schober D (2014) Strategic behavior of energy suppliers in balancing markets under increased renewable supply. Paper presented at the European Conference of the International Association for Energy Economics, Rome 28-30 October 2014 
90. Connect Energy Economics (2014) Leitstudie Strommarkt. Arbeitspaket Optimierung des Strommarktdesigns. Studie im Auftrag des Bundesministeriums für Wirtschaft und Energie. Endbericht, Berlin

91. Lehmann P, Brandt R, Gawel E, Heim S, Korte K, Löschel A, Massier P, Reeg M, Schober D, Wassermann S (2015) Capacity payments to secure electricity supply? On the future of Germany's power market design. Energy, Sustainability and Society 5(1):15. https://doi.org/10.1186/s13705-015-0039-7

92. de Groot M, Crijns-Graus W, Harmsen R (2017) The effects of variable renewable electricity on energy efficiency and full load hours of fossil-fired power plants in the European Union. Energy 138:575-589 https://doi.org/10. 1016/j.energy.2017.07.085

93. Elberg C, Growitsch C, Höffler F, Richter J (2012) Untersuchungen zu einem zukunftsfähigen Strommarktdesign. Studie im Auftrag des Bundesministerium für Wirtschaft und Technologie (BMWi). Energiewirtschaftliches Institut an der Universität zu Köln (EWI), Köln

94. Ecke J, Herrmann N, Hilmes U, Kremp R, Macharey U, Nolde A, Wolter H, Zander W (2013) Ein zukunftsfähiges Energiemarktdesign für Deutschland. Studie im Auftrag des Verbands Kommunaler Unternehmen (VKU). VKU, Berlin

95. Matthes FC, Schlemmermeier B, Diermann C, Hermann H, von Hammerstein C (2012) Focused capacity markets. A new market design for the transition to a new energy system. A study for the WWF Germany Environmental Foundation. Öko-Institut, LBD Beratungsgesellschaft, RAUE LLP, Berlin

96. Maurer C (2013) Versorgungssicherheit effizient gestalten: Zur Diskussion um Kapazitätsmechanismen in Deutschland. In: Agora Energiewende (ed) Kapazitätsmarkt oder strategische Reserve: Was ist der nächste Schritt? Eine Übersicht über die in der Diskussion befindlichen Modelle zur Gewährleistung der Versorgungssicherheit in Deutschland. Agora Energiewende, Berlin, pp 27-35

97. Kunz F (2013) Improving congestion management: how to facilitate the integration of renewable generation in Germany. Energy J 34(4):55-78. https://doi.org/10.5547/01956574.34.4.4.

98. Trommler M, Dotzauer M, Barchmann T, Matthischke S, Brosowski A, Keil A Gerigk U, Lange C, Kretschmer K (2016) RegioBalance - BioenergieFlexibilisierung als regionale Ausgleichsoption in deutschen Stromverteilernetzen. Deutsches Biomasseforschungszentrum (DBFZ), Energy2market, Leipzig

99. StrommarktG Gesetz zur Weiterentwicklung des Strommarktes (Strommarktgesetz) vom 26. Juli 2016. Bundesgesetzblatt Jahrgang 2016 Teil I Nr. 37:1786-1817.

100. BMWi [Federal Ministry for Economic Affairs and Energy] (2016) Kapazitätsreserveverordnung (KapResV) - Verordnung zur Regelung des Verfahrens der Beschaffung, des Einsatzes und der Abrechnung einer Kapazitätsreserve. Referentenentwurf, Berlin

101. Deutsche Umwelthilfe e.V (2015) Stellungnahme der Deutschen Umwelthilfe e.V. zum Referentenentwurf des BMWi zur Verordnung zur Regelung des Verfahrens der Beschaffung, des Einsatzes und der Abrechnung einer Kapazitätsreserve (Kapazitätsreserveverordnung). Deutsche Umwelthilfe e.V, Berlin

102. Bundesnetzagentur (2017) BK6-15-158. Festlegungsverfahren zu den Ausschreibungsbedingungen und Veröffentlichungspflichten für Sekundärregelung. Beschlusskammer 6 der Bundesnetzagentur, Bonn

103. Bundesnetzagentur (2017) BK6-15-159. Festlegungsverfahren zu den Ausschreibungsbedingungen und Veröffentlichungspflichten für Minutenreserve. Beschlusskammer 6 der Bundesnetzagentur, Bonn

104. Andor M, Voss A (2016) Optimal renewable-energy promotion: capacity subsidies vs. generation subsidies. Resour Energy Econ 45:144-158. https:// doi.org/10.1016/j.reseneeco.2016.06.002

105. Vollprecht J, Altrock M (2016) Die EEG-Novelle 2017: Von Ausschreibungen bis zuschaltbare Lasten. EnWZ 5(9):387-396

106. Anatolitis V, Welisch M (2017) Putting renewable energy auctions into action-an agent-based model of onshore wind power auctions in Germany. Energy Policy 110(Supplement C):394-402 https://doi.org/10.1016/ j.enpol.2017.08.024

107. Bundesverband Bioenergie e.V. (BBE), Deutscher Bauernverband e.V. (DBV), Fachverband Biogas e.V. (FvB), Fachverband Holzenergie (FVH) (2017) Bundesregierung muss bei EEG-Ausschreibungen nachbessern. Gemeinsame Pressemitteilung. https://www.bioenergie.de/presse/strom/bundesregierungmuss-bei-eeg-ausschreibungen-nachbessern. Accessed 27 Sept 2017.

108. KWKG 2016 Kraft-Wärme-Kopplungsgesetz vom 21. Dezember 2015 (BGBI. I S. 2498), das durch Artikel 3 des Gesetzes vom 17. Juli 2017 (BGBI. I S. 2532) geändert worden ist.
109. BMWi [Federal Ministry for Economic Affairs and Energy] (2017) Bundesregierung schafft die Grundlage für Ausschreibungen für KWKAnlagen und innovative KWK-Systeme sowie zur gemeinsamen Ausschreibungen für Windenergieanlagen an Land und Solaranlagen. https://www.bmwi.de/Redaktion/DE/Pressemitteilungen/2017/20170517-brschafft-grundlage-fuer-kwk-ausschreibung.html. Accessed 15 Aug 2017.

110. Frontier Economics, Formaet Services (2014) Strommarkt in Deutschland Gewährleistet das derzeitige Marktdesign Versorgungssicherheit? Bericht für das Bundesministerium für Wirtschaft und Energie (BMWi). Frontier Economics, London

111. European Network of Transmission System Operators for Electricity (ENTSOE) (2014) Scenario outlook and adequacy forecast 2014-2030. https:// docstore.entsoe.eu/Documents/TYNDP\%20documents/TYNDP\%202014/ 140602_SOAF\%202014-2030.pdf. Accessed 15 Apr 2018.

112. 50Hertz, Amprion, TenneT, TransnetBW (2014) Bericht der deutschen Übertragungsnetzbetreiber zur Leistungsbilanz 2014 nach EnWG § 12 Abs. 4 und 5. https://www.bmwi.de/Redaktion/DE/Publikationen/Energie/ leistungsbilanbericht-2014.html. Accessed 04 July 2017.

113. Unruh GC (2000) Understanding carbon lock-in. Energy Policy 28(12):817830. https://doi.org/10.1016/s0301-4215(00)00070-7

114. High-Level Commission on Carbon Prices (2017) Report of the high-level commission on carbon prices. Carbon pricing leadership coalition.

115. Wehnert T, Best B, Andreeva T (2017) Kohleausstieg - Analyse von aktuellen Diskussionsvorschlägen und Studien. Eine Studie im Auftrag des Naturschutzbund Deutschland (NABU). Wuppertal Institut für Klima, Umwelt, Energie, Wuppertal

116. Gawel E, Strunz S (2015) Klimaabgabe für Kohlekraftwerke: Ein richtiger Schritt zur Erreichung des Klimaziels? ifo Schnelldienst 68(14):8-11

117. Jaffe $A B$, Newell RG, Stavins RN (2005) A tale of two market failures: technology and environmental policy. Ecol Econ 54(2-3):164-174. https:// doi.org/10.1016/j.ecolecon.2004.12.027

118. Gallagher KS, Grübler A, Kuhl L, Nemet G, Wilson C (2012) The energy technology innovation system. Annu Rev Environ Resour 37:137-162. https://doi.org/10.1146/annurev-environ-060311-133915

119. Jacobsson S, Bergek A (2011) Innovation system analyses and sustainability transitions: contributions and suggestions for research. Environmental Innovation and Societal Transitions 1(1):41-57. https://doi.org/10.1016/j.eist. 2011.04.006

120. Sandén BA, Azar C (2005) Near-term technology policies for long-term climate targets-economy wide versus technology specific approaches. Energy Policy 33(12):1557-1576. https://doi.org/10.1016/j.enpol.2004.01.012

121. Scheftelowitz M, Thrän D (2016) Biomasse im EEG 2016. Hintergrundpapier zur Situation der Bestandsanlagen in den verschiedenen Bundesländern Deutsches Biomasseforschungszentrum (DBFZ), Helmholtz-Zentrum für Umweltforschung - UFZ, Leipzig

122. Eucken W (1952/1990) Grundsätze der Wirtschaftspolitik. 7th edn. J. C. B. Mohr (Paul Siebeck), Tübingen

123. 50Hertz, Amprion, Tenne T, Transnet BW (2017) EEG-Jahresabrechnungen auf der Informationsplattform der deutschen Übertragungsnetzbetreiber (ÜNB). https://www.netztransparenz.de/EEG/Jahresabrechnungen . Accessed 4 July 2017

124. EPEXSpot (2016) Market data - day-ahead auction. European power exchange (EPEX). http://www.epexspot.com/en/market-data. Accessed 31 Aug 2016

125. Bundesnetzagentur (2014) Angaben zur Flexibilitätsprämie. Personal communication

126. "et"-Redaktion (2017) Sinkende Preisdifferenz von Gas zu Kohle sorgt für neue Lage am Strommarkt. Energiewirtschaftliche Tagesfragen 67(1/2):47-48

127. Hecking H, Cam E, Schönfisch M, Schulte S (2017) Aktuelle Entwicklungen auf den Kohle- und Gasmärkten und ihre Rückwirkungen auf die Merit Order. Energiewirtschaftliche Tagesfragen 67(6):34-38 